\title{
Co-processing of wood and wheat straw derived pyrolysis oils with FCC feed-Product distribution and effect of deoxygenation
}

Eschenbacher, Andreas; Myrstad, Trond; Bech, Niels; Duus, Jens Øllgaard; Li, Chengxin; Jensen, Peter Arendt; Henriksen, Ulrik Birk; Ahrenfeldt, Jesper; Mentzel, Uffe Vie; Jensen, Anker Degn

\section{Published in:}

Fuel

Link to article, DOI:

10.1016/j.fuel.2019.116312

Publication date:

2020

Document Version

Peer reviewed version

Link back to DTU Orbit

Citation (APA):

Eschenbacher, A., Myrstad, T., Bech, N., Duus, J. Ø., Li, C., Jensen, P. A., Henriksen, U. B., Ahrenfeldt, J., Mentzel, U. V., \& Jensen, A. D. (2020). Co-processing of wood and wheat straw derived pyrolysis oils with FCC feed-Product distribution and effect of deoxygenation. Fuel, 260, [116312]. https://doi.org/10.1016/j.fuel.2019.116312

\section{General rights}

Copyright and moral rights for the publications made accessible in the public portal are retained by the authors and/or other copyright owners and it is a condition of accessing publications that users recognise and abide by the legal requirements associated with these rights.

- Users may download and print one copy of any publication from the public portal for the purpose of private study or research.

- You may not further distribute the material or use it for any profit-making activity or commercial gain

- You may freely distribute the URL identifying the publication in the public portal 


\title{
Co-processing of Wood and Wheat Straw Derived Pyrolysis Oils with FCC Feed-Product Distribution and Effect of Deoxygenation
}

\author{
Andreas Eschenbacher ${ }^{\mathrm{a}}$, Trond Myrstad ${ }^{\mathrm{b}}$, Niels Bech ${ }^{\mathrm{c}}$, Jens $_{\text {Øllgaard Duus }}^{\mathrm{d}}$, \\ Chengxin Lid ${ }^{\mathrm{d}}$, Peter Arendt Jensen ${ }^{\mathrm{a}}$, Ulrik Birk Henriksen ${ }^{\mathrm{a}}$, Jesper \\ Ahrenfeldt $^{\mathrm{a}}$, Uffe Vie Mentzel ${ }^{\mathrm{e}}$, Anker Degn Jensen ${ }^{\mathrm{a}, *}$ \\ ${ }^{a}$ Department of Chemical and Biochemical Engineering, Technical University of Denmark, \\ Søltofts Plads Building 229, Kgs. Lyngby, 2800, Denmark \\ ${ }^{b}$ Forskningsenter Rotvoll, Equinor, Arkitekt Ebbels vei 10, Ranheim, 7053, Norway \\ ${ }^{c}$ Equinor Danmark A/S, Melbyvej 10, Kalundborg, 4400, Denmark \\ ${ }^{d}$ Department of Chemistry, Technical University of Denmark, Kemitorvet Building 207, \\ Kgs. Lyngby, 2800, Denmark \\ ${ }^{e}$ Haldor Topsøe A/S, Haldor Topsøes Allé 1, Kgs. Lyngby, 2800, Denmark
}

\begin{abstract}
The behavior of bio-oils when co-processed with conventional fossil feed in a fluid catalytic cracking (FCC) unit is suitably tested using a microactivity testing unit (MAT). In the present study, non-catalytic fast pyrolysis oils originating from wood and wheat straw were co-processed in a MAT at a 20/80 weight blend (bio-oil/FCC feed). In addition, bio-oil obtained from deoxygenating the straw derived vapors over a steamed HZSM-5 $/ \mathrm{Al}_{2} \mathrm{O}_{3}$ extrudate catalyst was tested. The bio-oils were characterized for elemental composition and moisture content to calculate energy recoveries, amounting to $35 \%$ and $30 \%$ for the noncatalytically obtained wood and straw oils, while it was $19 \%$ for the partly deoxygenated straw oil. Wood oil showed higher acidity $(61 \mathrm{mg} \mathrm{KOH} / \mathrm{g})$ and molar $\mathrm{O} / \mathrm{C}$ ratio (0.35) compared to straw oil $(54 \mathrm{mg} \mathrm{KOH} / \mathrm{g}$ and $\mathrm{O} / \mathrm{C}=$ 0.24). The acidity and $\mathrm{O} / \mathrm{C}$ ratio was reduced for the straw-derived bio-oil from catalytic vapor treatment $(3 \mathrm{mg} \mathrm{KOH} / \mathrm{g}, \mathrm{O} / \mathrm{C}=0.08)$. At constant conversion
\end{abstract}

\footnotetext{
${ }^{*}$ Corresponding author.

Email addresses: aesc@kt.dtu.dk (Andreas Eschenbacher), jduus@kemi.dtu.dk (Jens Øllgaard Duus), cheli@kemi.dtu.dk (Chengxin Li), paj@kt.dtu.dk (Peter Arendt Jensen), ubhe@kt.dtu.dk (Ulrik Birk Henriksen), jeah@kt.dtu.dk (Jesper Ahrenfeldt), ufvm@topsoe.com (Uffe Vie Mentzel), aj@kt.dtu.dk (Anker Degn Jensen)
} 
$(77.5 \%)$ at the MAT, the wood pyrolysis oil showed a product distribution quite similar to the reference oil while the wheat straw pyrolysis oil gave a $1.6 \%$ points higher coke yield and a $1.2 \%$ points lower liquid petroleum gas (LPG) yield. For the catalytically treated wheat straw pyrolysis oil, an even higher coke yield (2.6\% points) and $1.9 \%$ points lower LPG yield resulted. The observations are attributed to the higher content of aromatics, phenolics, and nitrogen containing compounds of the catalytically upgraded straw fast pyrolysis oil.

Keywords: FCC, Co-processing, Deoxygenation, Straw, Pyrolysis oil, HZSM-5

\section{Introduction}

Co-feeding of biomass-derived fast pyrolysis (FP) oils with fossil oil in oil 3 refineries can attenuate our dependence on crude oil. Advantageously, FP pro4 cesses are generally flexible with respect to biomass feedstocks [1] 8 . However, 5 raw pyrolysis oil is comprised of hundreds of oxygenated species which makes 6 the oil acidic, instable, and capable of dissolving high amounts of water compared to the mostly aliphatic and hydrophobic refinery feedstock 9 12] In order to improve the miscibility of fossil oils with biomass FP oils, the pyrolysis vapors can be (partly) deoxygenated under atmospheric conditions over solid acid catalysts [13]. In this way, the renewable oils could be upgraded using existing refinery infrastructure [14]. The refineries' acceptance for co-processing biomass-derived oils is crucial, especially since the bio-oil properties may fluctuate due to the heterogeneity and variety of the feedstock. It is noted that due to the high acidity of raw bio-oils, separate feed lines and tanks with stainless steel cladding would be necessary for bio-oil co-processing to minimize corrosion [15, 16] . Recently, Stefanidis et al. [17] reviewed studies [15, 18, 21] that investigated co-feeding of raw FP bio-oils and the resulting shift in product distribution. Reduced gasoline and light cycle oil (LCO) yields were attributed to increased coke formation and the dilution of the reactant stream with water from the raw bio-oil feed. Most studies reported reduced hydrogen yields, which was attributed to the introduction of the hydrogen-deficit bio-oil. The shifts in 
gasoline, LCO, and coke yield were not consistent across all studies, which may be related to the difficulty in blending and feeding raw bio-oil with fossil oil and the different experimental conditions [17. Pinho et al. 22 conducted tests in a demonstration-scale FCC unit using $450 \mathrm{~kg}$ catalyst and feeding $150 \mathrm{~kg} / \mathrm{h}$ of 10/90 and 20/80 weight ratios of bio-oil/vacuum gas oil (VGO). In both cases, approximately $30 \%$ by weight of the renewable carbon present in the bio-oil was preserved in the liquid effluent. In a later study [15] at similar scale (oil feeding rate $200 \mathrm{~kg} / \mathrm{h}$ ), 5/95 and 10/90 bio-oil/VGO blends were tested. The pine wood derived bio-oil contained 31.9 wt $\%$ moisture and 32.8 wt $\% \mathrm{O}$ on dry basis (d.b.). Liquid product streams of gasoline and LCO contained $1 \mathrm{wt} \%$ of renewable carbon respectively for the 5/95 bio-oil/VGO blend. Interestingly, the coke yield decreased when co-processing $5 \mathrm{wt} \%$ bio-oil while no benefits with respect to coking resulted when blending $10 \mathrm{wt} \%$ bio-oil.

Since the majority of the laboratory and pilot-scale FCC co-processing tests resulted in higher coke production when introducing raw bio-oil (especially at high blending ratios), some authors have investigated co-feeding of stabilized bio-oils with reduced oxygen content that were obtained by catalytic deoxygenation of the pyrolysis vapors prior to condensation. Catalytic deoxygenation of FP oils not only reduces the extent of oil aging and plant corrosion, but it also improves the evaporation properties and the miscibility with fossil feedstock [4, 10, 12, 23, 24]. This has the potential to increase the fraction of bio-oil being co-processed and thus increase the proportion of renewable carbon in the desired refinery products. Compared to studies co-processing partly deoxygenated oils obtained by hydrodeoxygenation (HDO) of raw FP oils [17, studies on co-processing of catalytic fast pyrolysis (CFP) oils are fewer and more research is needed to properly evaluate this approach. Table 1 summarizes studies in which bio-oils (all wood derived) obtained by CFP over HZSM-5 were tested for blending with fossil feed. Agblevor et al. 25] carried out catalytic cracking of a CFP oil blended with 85 wt\% standard gas oil over an equilibrated FCC catalyst (E-cat) in a laboratory catalyst evaluation unit. The CFP oil was produced via HZSM-5 catalytic pyrolysis of poplar wood in a fluidized-bed reactor 
at $450^{\circ} \mathrm{C}$. Only the fraction that was collected from the electrostatic precipitator was used for co-processing, which accounted for $50 \mathrm{wt} \%$ of the total bio-oil and had relatively low moisture $(8.9 \mathrm{wt} \%)$ and oxygen content (22 wt\% on dry basis), a total acid number (TAN) of $41 \mathrm{mg} \mathrm{KOH} / \mathrm{g}$ oil and a carbon content of $71 \mathrm{wt} \%$ (dry basis). The CFP oil was shown to be stable since only minimal increase in viscosity after long-term storage at ambient conditions was observed and high temperature simulated distillation to $\sim 600{ }^{\circ} \mathrm{C}$ could be carried out with only minor char formation. Co-processing standard gas oil with CFP oil did not have any obvious adverse effects on the yield of the various product fractions, especially gasoline. However, the blend produced less hydrogen and slightly less coke than standard gas oil, which was attributed to the presence of steam and in situ generated hydrogen that moderated coke formation. Radiocarbon analysis showed that the bio-carbon content of the cracked liquid products was $3 \mathrm{wt} \%$. Thegarid et al. 26] reported almost two fold higher coke yields and enhanced dry gas and $\mathrm{CO}_{2}$ yields when co-feeding 10 wt\% CFP oil (beech wood, 27 wt\% O) with VGO. These researchers found enhanced gasoline and decreased LCO oil yields upon co-processing. Lindfors et al. [19] tested CFP oil (pine wood, 22 wt $\%$ O d.b.) at a blending ratio of 20/80 with VGO and observed a doubling in coke yield from 5 to $10 \mathrm{wt} \%$ and an increase in both gasoline, LCO, and dry gas, while the heavy cycle oil and slurry oil $\left(>370^{\circ} \mathrm{C}(\mathrm{HCO})\right.$ decreased. This is in agreement with Marker et al. [16] who found that the acidic bio-oils increased the cracking of the VGO and shifted the yields toward increased light ends, which is an economically attractive outcome. Wang et al. 4] obtained CFP oil with 73 wt\% C, 5.6 wt\% $\mathrm{H}$ and 19.5 wt\% O using Fe/HZSM-5 and reported $7 \mathrm{wt} \%$ (bio)carbon recovery in the gasoline fraction when $10 \mathrm{wt} \%$ bio-oil was added to VGO. The results indicate that increased $\mathrm{C} / \mathrm{O}$ ratios of upgraded oils can increase the (bio)carbon recovery in the gasoline product fraction, and the lower $\mathrm{C}$ recovery reported by Agblevor et al. 25] may be reasoned by the higher blending ratio and lower $\mathrm{C} / \mathrm{O}$ ratio compared to Wang et al. 4]. 
Table 1. Shift in gasoline, light cycle oil (LCO), coke, and hydrogen yields [wt\%] when co-processing catalytic pyrolysis oil (CPO) with vacuum gas oil. Adapted from Stefanidis et al. 17] and amended by the oxygen and and carbon content of the upgraded bio-oils used for co-feeding.

\begin{tabular}{|c|c|c|c|c|c|c|c|c|}
\hline Ref. & Reactor & $\begin{array}{c}\mathrm{O} \text { wt\%d.b. } \\
\text { bio-oil }\end{array}$ & $\begin{array}{c}\mathrm{C} \text { wt\%d.b. } \\
\text { bio-oil }\end{array}$ & bio-oil/VGO & $\begin{array}{c}\text { Change Gasoline } \\
\text { (wt\%) }\end{array}$ & $\begin{array}{c}\text { Change LCO } \\
\text { (wt\%) }\end{array}$ & $\begin{array}{c}\text { Change Coke } \\
\text { (wt\%) }\end{array}$ & $\begin{array}{c}\text { Change Hydrogen } \\
\text { (wt } \%)\end{array}$ \\
\hline 25 & $\begin{array}{l}\text { Lab-scale } \\
\text { fluidized-bed reactor }\end{array}$ & 21.9 & 71.2 & $15 / 85$ & +0.4 & +0.1 & -0.3 & -0.05 \\
\hline 26 & $\begin{array}{l}\text { Lab-scale } \\
\text { fixed-bed reactor } \\
\text { Lab-scale }\end{array}$ & 27.0 & 66.0 & $10 / 90$ & $+1.7-+15.1$ & $-13.0-0.0$ & $+1.6-+1.9$ & $-0.3--0.1$ \\
\hline 19 & $\begin{array}{l}\text { Lab-scale } \\
\text { fixed-bed reactor }\end{array}$ & 22.0 & 71.5 & $20 / 80$ & +3.0 & +2.0 & +5.0 & Not reported \\
\hline 4 & $\begin{array}{l}\text { Pilot-scale } \\
\text { circulating riser }\end{array}$ & 19.5 & 73.1 & $10 / 90$ & -0.1 & +0.5 & -0.1 & -0.04 \\
\hline
\end{tabular}
of regular FCC feed with pyrolysis oils from different feeds (pine and wheat straw). In addition, a catalytically deoxygenated oil obtained from wheat straw was included in the FCC blending tests. While the potential of wheat straw as a renewable source of fuels and chemicals via FP has been recognized by others [7, 8, 27, 30, to the best of our knowledge wheat straw derived pyrolysis oils (raw or deoxygenated) have not yet been tested for FCC co-feeding.

At fixed blending ratios between bio-oil and the FCC reference feed (20/80 by weight), the blend was tested at a MAT unit at different catalyst-to-oil ratios (cat/oil) in order to obtain complete yield curves and assess the impact of the addition of bio-oils on the product distribution.

\section{Experimental section}

\subsection{Bio-oil generation}

\subsubsection{Pyrolysis}

The experimental set-up, procedure, and the characteristics of the wood (pine) and wheat straw feedstock are described elsewhere 31. Briefly, biomass was fed at $\sim 200 \mathrm{~g} / \mathrm{h}$ to an ablative $\mathrm{FP}$ unit, operated at $500{ }^{\circ} \mathrm{C}$ using pine and at $530^{\circ} \mathrm{C}$ using wheat straw as feedstock. Char separation was achieved by cyclones $\left(450^{\circ} \mathrm{C}\right)$ and hot gas filtration using a ceramic filter candle $350{ }^{\circ} \mathrm{C}$ upstream the ex-situ located catalytic fixed bed. Vapors were condensed in three 
stages: At $4{ }^{\circ} \mathrm{C}$, a series of metal impingers was used, followed by an electrostatic precipitator (ESP) operated at room temperature, and a series of glass impingers cooled to $-60^{\circ} \mathrm{C}$. Noncondensable gases (NCG) were analyzed using NDIR and GC-TCD/FID. For both pine and straw feedstock, non-catalytic thermal reference oils were obtained by filling the catalytic reactor with $95 \mathrm{~g}$ SiC. To obtain partly deoxygenated wheat straw FP oil, 260 g HZSM-5/ $\mathrm{Al}_{2} \mathrm{O}_{3}$ extrudates (Extr) consisting of $65 \%$ HZSM-5 and $35 \% \mathrm{Al}_{2} \mathrm{O}_{3}$ binder were provided by Haldor Topsøe A/S and steamed prior to its use by injecting water (2 $\mathrm{ml} / \mathrm{min})$ into a preheated nitrogen stream $(4 \mathrm{Nl} / \mathrm{min})$ and passing the steam ( $\sim 30$ vol- $\%$ ) for $5 \mathrm{~h}$ through the catalyst bed kept at $500{ }^{\circ} \mathrm{C}$ under atmospheric pressure conditions. The steamed extrudates were crushed, screened, and the fraction between $250-850 \mu \mathrm{m}$ was used for the catalytic runs. Oil was collected first over the freshly steamed extrudate (Extr-st) after feeding a ratio of dry, ash free (daf) biomass-to-catalyst ratio (w/w, B:C) of 1.9. Subsequently, oil was collected over the pre-coked extrudate (Extr-st-u) during continued biomass feeding at $\mathrm{B}: \mathrm{C}=1.9-5.6$. Coke combustion after the second upgrading interval was conducted according to the conditions described by Eschenbacher et al. 31. and allowed closing the mass balance to $\sim 94 \%$. Only the latter oil was used in the MAT experiments.

\subsubsection{Oil characterization.}

The oil characterization methodology was reported earlier 31, 32]. Karl Fischer titration, elemental analysis and GC-MS/FID was conducted for the mixture of oil fractions (mix OF) obtained at the $4{ }^{\circ} \mathrm{C}$, the $\mathrm{ESP}$, and the $-60^{\circ} \mathrm{C}$ condensation stage. The mixtures were prepared gravimetrically according to the oil's yield at each condensation stage. The organics contained in the phase separated oil and water fractions are referred to as liquid-range organics. Since the sulfur concentration was below the detection limit of the elemental analyzer, the oil fractions (OF) were subjected to total sulfur analysis according to ASTM method D5453. In addition, analysis of the TAN, basic nitrogen content and evaporation characteristics was conducted, and the oils were analyzed using ${ }^{1} \mathrm{H}$, 
${ }^{13} \mathrm{C}$, and 2D HSQC NMR. For the investigation of the oils' evaporation behavior in a thermogravimetric analyzer (TGA simulated distillation), about $20 \mathrm{mg}$ of oil were prepared into a Pt crucible with lid shortly before start of the heating. The temperature was ramped to $650^{\circ} \mathrm{C}$ at $10^{\circ} \mathrm{C} / \mathrm{min}$ under $\mathrm{N}_{2}$ atmosphere. For details regarding the GPC system used for size exclusion chromatography of the oils, the reader is referred to our earlier work [31. It should be noted that for mixtures of chemically similar compounds, the components with higher MW elute at lower retention volumes.

\subsection{MAT experiments}

\subsubsection{FCC catalyst pre-deactivation}

A commercial resid FCC catalyst was used in the study. The FCC catalyst was first impregnated with nickel and vanadium naphthenates according to the Mitchell method [34]. The target metals level after impregnation were 2500 ppm $\mathrm{V}, 1667 \mathrm{ppm} \mathrm{Ni}$, i.e. a target $\mathrm{V}: \mathrm{Ni}$ ratio of $3: 2$. Then the FCC catalyst was deactivated by Cyclic Propylene Steaming (CPS) [35]. The CPS deactivation was performed as recommended by Wallenstein et al.[36], but with some minor modifications: The deactivation temperature was $795^{\circ} \mathrm{C}$, and the number of deactivation cycles was 40 . In addition, two deactivation cycles were run during the last part of heating of the deactivation unit. After CPS deactivation, the FCC catalyst had a zeolite surface area of $147 \mathrm{~m}^{2} / \mathrm{g}$ (micropores) and a matrix surface area of $36 \mathrm{~m}^{2} / \mathrm{g}$ (mesopores), resulting in a total surface area of $183 \mathrm{~m}^{2} / \mathrm{g}$.

\subsubsection{FCC feed properties}

A North Sea Atmospheric Resid with properties as shown in Table 2 was used as reference feed in the MAT experiments. The boiling point distribution of the reference feed based on high-temperature simulated distillation (Fig. S1) shows that the feed mostly (85\%) contained heavy cycle oil (HCO), boiling above $350{ }^{\circ} \mathrm{C}$, but it also contained approximately $15 \mathrm{wt} \%$ with a boiling point below $350^{\circ} \mathrm{C}$, corresponding to light cycle oil (LCO) with a defined boiling point range of $225-350{ }^{\circ} \mathrm{C}$. Three different pyrolysis oils were tested and their properties are described in more detail in Section 3.1 and Table 3 . The oxygen content of 
the reference oil is assumed to be close to zero and the TAN is expected to be $\sim 1 \mathrm{mg} \mathrm{KOH} / \mathrm{g}$ based on TAN-numbers for other North Sea atmospheric resids. The bio-oils tested in the MAT unit were blended with the reference feed in the ratio $20 / 80$ by weight.

Table 2. Properties of FCC reference feed

\begin{tabular}{lc}
\hline Density $(\mathrm{kg} / \mathrm{l})$ & 0.9342 \\
Conradson Carbon Content (wt\%) & 3.78 \\
Sulphur (wt\%) & 0.46 \\
Vanadium (ppm) & 2.6 \\
$\mathrm{Ni}(\mathrm{ppm})$ & 4 \\
$\mathrm{Na}(\mathrm{ppm})$ & 2.8 \\
$\mathrm{Fe}(\mathrm{ppm})$ & 3.4 \\
Basic Nitrogen (ppm) & 620 \\
\hline
\end{tabular}

\subsection{MAT Testing}

The MAT experiments were done in a fully automated MAT unit, as described by Myrstad and Engan 33, with an oil injection time of $30 \mathrm{~s}$ and a reaction temperature of $525{ }^{\circ} \mathrm{C}$. The catalyst/oil ratio in the experiments was varied by varying the amount of feed injected over a bed containing $3 \mathrm{~g}$ catalyst. For the catalytic cracking, the conversion [\%] was defined as

$$
\text { Conversion }=100-(\text { light cycle oil }(\mathrm{LCO})+\text { heavy cycle oil }(\mathrm{HCO})) \text {. }
$$

Besides light gases and coke formed on the catalyst, liquefied petroleum gas (LPG) was defined as $\mathrm{C}_{3}+\mathrm{C}_{4}$ compounds and naphtha was defined as $\mathrm{C}_{5}+$ compounds up to a boiling point of $221^{\circ} \mathrm{C}$.

As will be shown in Section 3.1, the bio-oils - especially the catalytically treated one - contained some components in the naphtha range. Since the biomass derived components are more reactive, it is likely that they are converted to both heavier and lighter product components during the cracking and the calculation of conversion was not adjusted for this aspect.

All results were normalized against the mass balance. Thus, the differences in the mass balances are the largest source of uncertainty in the experiments. 
To reduce the uncertainty, only experiments with mass balances of $100 \pm 2.5 \%$ were accepted. The standard deviation (SD) was not calculated in this paper but has earlier been reported to $0.51 \mathrm{wt} \%$ for 20 replicates 33 . The different yield curves are drawn by using linear, logarithmic, or exponential regression. The regression coefficient $\mathrm{R}^{\wedge} 2$ can be used as an indication on the quality of the results. For the conversion vs. catalyst/oil curves and most yields $\mathrm{R}^{2}$ was $>0.95$. $\mathrm{R}^{2}$ for the coke and naphtha yield curve were lower $(\sim 0.8)$.

\section{Results}

\subsection{Bio-oil Generation \& Characterization}

\subsubsection{Product Distribution Bio-Oil}

Fig. S3 shows the product distributions from bio-oil generation (yields based on dry, ash-free biomass; reaction water excludes biomass induced moisture). As was noted earlier 31, compared to oil collected with an empty catalytic reactor, passing the vapors over a $\mathrm{SiC}$ bed slightly decreased the oil yields and its oxygen content. The coke yield amounted to $\sim 0.1 \mathrm{wt} \%$ of fed biomass when using the $\mathrm{SiC}$ bed, and to $4.2 \mathrm{wt} \%$ using the steamed HZSM-5/ $\mathrm{Al}_{2} \mathrm{O}_{3}$ extrudate after feeding of biomass corresponding to $\mathrm{B}: \mathrm{C}=0-5.6$. Higher char and gas yields resulted when using wheat straw compared to wood, which led to a significantly lower yield of liquid-range organics, see Fig. S3. This can be attributed to the high ash content of straw $(5.9 \%)$ compared to wood $(0.2 \%)$, which is known to promote cracking and char formation [2, 5. The upgrading of the vapors over the catalyst severely decreased the yield of liquid-range organics at B:C $=1.9$ (at enhanced gas formation), while for $\mathrm{B}: \mathrm{C}=1.9-5.6$ the losses to gas decreased and higher yields of liquid-range organics were obtained, yet only $~ 50 \%$ compared to $\mathrm{SiC}$ (see Fig. S3).

\subsubsection{Catalyst characterization}

Catalyst characterization of the HZSM-5/ $\mathrm{Al}_{2} \mathrm{O}_{3}$ extrudate has been reported in earlier work 32 . Table S1 and adjacent section in the supporting information summarize the physicochemical characterization of the catalyst used for deoxygenation of the wheat straw FP vapors. 


\subsubsection{Oil Properties}

Table 3 provides an overview of important properties of the bio-oils tested for co-processing in the MAT. Each oil was prepared as a mixture of oil fractions obtained at three different condensation stages, and the analysis of these single oils $\left(4^{\circ} \mathrm{C} \mathrm{OF}, \mathrm{ESP} \mathrm{OF},-60^{\circ} \mathrm{C} \mathrm{OF}\right)$ is provided in Table S2-S4. A comparison of the straw oils shows that a higher fraction of the organics content was recovered in the water fraction (mix WF) for oils with higher oxygen content (Tables S3-S4). Along with the oils' yield, moisture and oxygen content (wt\% d.b.), Table 3 lists the oils' TAN content and char remains upon TGA simulated distillation, with both the solid remains of the dry organics content at $300^{\circ} \mathrm{C}$ and $500^{\circ} \mathrm{C}$ indicated. The weight loss curves during TGA simulated distillation are shown in Fig. 17. The TAN content refers to the "wet" oil samples, i.e. the oil fraction including the dissolved water. In addition, Table 3 includes sulphur analysis and density of the oils. Wood FP oil has 29.7 wt\% O (d.b.), which shows some reduction compared to the feedstock (41.9 wt\% O d.b.). Straw FP oil has a lower oxygen content and TAN compared to the wood oil (Table 3), however a slightly higher sulfur content (0.07 wt\%) which agrees with the $~ 10$ fold higher S concentration in the feedstock. While a deep deoxygenation (2.9 wt $\%$ O) was obtained for the catalytically upgraded oil at $\mathrm{B}: \mathrm{C}=1.9$, the yield of the oil fraction was only $3.5 \mathrm{wt} \%$ of daf straw. Over the coked catalyst with reduced activity $(\mathrm{B}: \mathrm{C}=1.9-5.6)$, oil with $8.8 \mathrm{wt} \% \mathrm{O}$ was obtained at almost three times higher oil yield (10 wt\%).

When oxygen is released as water during the cracking of oxygenates over acidic catalysts, hydrogen is depleted which leads to enriched aromatics content in the products but also rapid coke formation. In view of this, the effective hydrogen to carbon ratio (EHI) as defined by Chen et al. 34 can be used to assess the coking propensity of the product mixture. EHI is defined as $(\mathrm{H}-2 \mathrm{O}$ $-3 \mathrm{~N}-2 \mathrm{~S}) / \mathrm{C}$, where $\mathrm{H}, \mathrm{C}, \mathrm{O}, \mathrm{N}$, and $\mathrm{S}$ are atoms per unit weight of sample of hydrogen, carbon, oxygen, nitrogen and sulfur, respectively. All three bio-oils have $\mathrm{EHI}<1$, which is indicative of their hydrogen deficiency. Pine-derived oil 
Table 3. Overview of properties of bio-oil: Oils yield (not including $\mathrm{C}_{4}+$ measured in gas), density, moisture, elemental composition (d.b.), TAN, basic nitrogen content, and mass remaining with respect to dry organics content upon heating to $500{ }^{\circ} \mathrm{C}$ in a TGA (Pt crucible with lid, $10^{\circ} \mathrm{C} / \mathrm{min}$ heating rate, $150 \mathrm{~mL} / \mathrm{min}$ flowrate $\mathrm{N}_{2}$ ).

\begin{tabular}{lccc}
\hline & Pine, $\mathrm{SiC}$ & Straw, SiC & Straw, Extr-st-u \\
\hline B:C & $0-4.2$ & $0-11.0$ & $1.9-5.6$ \\
Yield of oil phase (OF) [wt\% of daf feed] & 25.5 & 19.4 & 10 \\
Density at $25^{\circ} \mathrm{C}[\mathrm{g} / \mathrm{ml}]$ & 1.1752 & 1.105 & 1.0162 \\
$\mathrm{H}_{2} \mathrm{O}[\%]$ & 7.8 & 14.7 & 2.3 \\
wt\% C (d.b.) & 63.7 & 69.9 & 79.8 \\
wt\% H (d.b.) & 6.5 & 7.1 & 7.9 \\
wt\% N (d.b.) & 0.2 & 1.6 & 3.6 \\
wt\% O (d.b.) & 29.7 & 21.4 & 8.8 \\
wt\% S (d.b.) & 0.01 & 0.07 & 0.14 \\
Higher heating value (HHV) $[\mathrm{MJ} / \mathrm{kg}]{ }^{*}$ & 26.8 & 30.50 & 36.2 \\
Effective hydrogen index (EHI) & 0.50 & 0.69 & 0.90 \\
TAN [mg KOH/g] & 60.8 & 54.4 & 3.4 \\
Basic nitrogen content [ppm] & 30 & 3920 & 5670 \\
Solid remains (w-\% d.b.) at $300{ }^{\circ} \mathrm{C} / 500^{\circ} \mathrm{C}$ & $44.0 / 17.2$ & $44.5 / 16.9$ & $17.7 / 5.9$
\end{tabular}

* HHV was calculated based on the elemental composition of the oil according to correlations reported by Channiwala et al. [35], and the EHI parameter was defined by Chen et al. 34].

showed the lowest EHI of 0.5 and lowest heating value $(26.8 \mathrm{MJ} / \mathrm{kg})$ due to its higher oxygen content, while EHI and HHV were higher for the wheat straw derived bio-oils, especially for the catalytically treated one.

Despite different $\mathrm{O}$ content and MW distribution, the evaporation of straw and pine oils obtained over SiC did not differ much (Fig. 1a, Table 3). The evaporation characteristics and TAN of the wheat straw derived FP oil improved by the catalytic treatment (Table 3. Analysis by size exclusion chromatography (SEC) shows several discernable components for the oils (Fig. 1p). For chemically similar compounds, a higher retention volume indicates a shift to lower molecular weight. Based on the elution of a dodecastyrene standard with MW 
$=1250 \mathrm{Da}$ at $7.57 \mathrm{~mL}$, the oils contain compounds with $\mathrm{MW}<1000 \mathrm{Da}$. The catalytically obtained straw derived oils show reduced contributions of high MW compounds and a more intense refractive index (RI) response of low MW compounds, especially the oil obtained at $\mathrm{B}: \mathrm{C}=0-1.9$. While the wood and straw derived oils show a similar distribution of low MW compounds eluting $>9.5$ $\mathrm{mL}$, wood oil obtained over SiC contains a higher amount of compounds with higher MW. The lower MW of the straw SiC oil is attributed to the additional cracking effect induced by the alkaline ashes (especially $\mathrm{K}$ ) during pyrolysis and possibly upon contact of the vapors with the chars collected at the hot gas filter $11,36,38$.
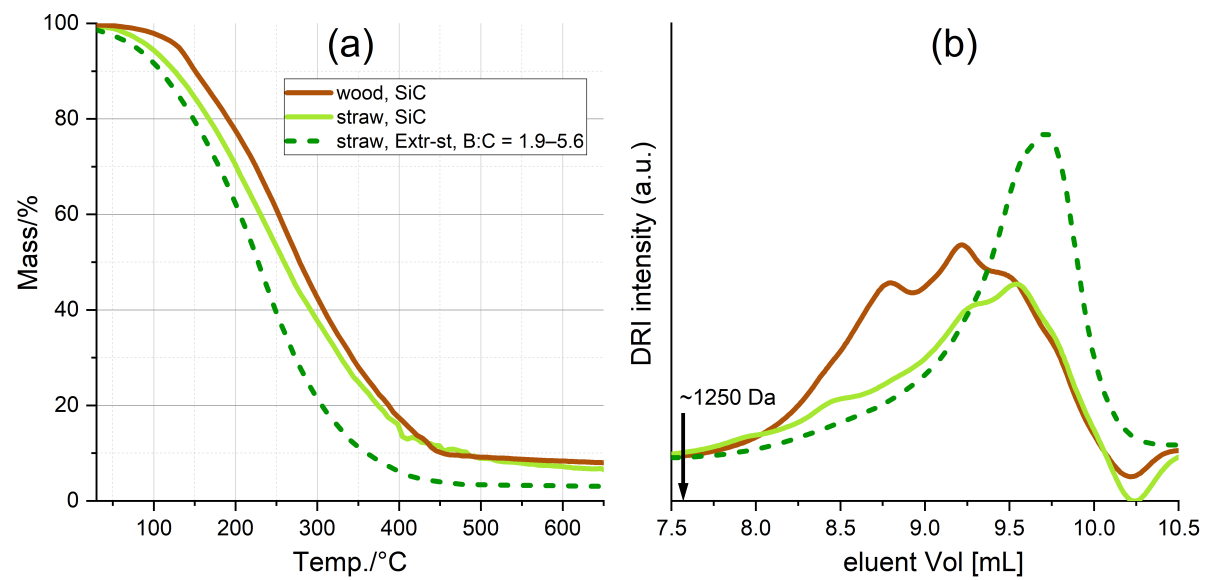

Fig. 1. (a) TGA simulated distillation curves of bio-oils. $20 \mathrm{mg}$ of oil heated at 10 ${ }^{\circ} \mathrm{C} / \mathrm{min}$ to $650{ }^{\circ} \mathrm{C}$ in $150 \mathrm{~mL} / \mathrm{min} \mathrm{N}_{2}$. (b) Differential refractive index (DRI) output for SEC chromatograms of bio-oils.

The quality of the condensed oils was further compared by their molar $\mathrm{H} / \mathrm{C}$ and $\mathrm{O} / \mathrm{C}$ ratios (see Fig. S4). The thermochemical conversion of both wood and straw produced oils with lower $\mathrm{O} / \mathrm{C}$ and $\mathrm{H} / \mathrm{C}$ ratio compared to the feedstock composition. Oil obtained from straw FP had a significantly lower O/C ratio (0.24) compared to wood oil $(0.35)$, while the $\mathrm{H} / \mathrm{C}$ ratio of the two oils was about the same (1.2). The energy recovery as phase separated oil fraction amounted to $35.2 \%$ and $30.4 \%$ for wood and straw oils obtained over the ex-situ $\mathrm{SiC}$ bed. For catalytically upgraded oils obtained from straw at B:C $=1.9-5.6$, 
the energy recovery was $18.6 \%$. Table 4 shows an overview of the proton NMR analysis of the oils, and the corresponding spectra are provided in Fig. S5. For straw derived oils, the most pronounced change upon catalytic upgrading of the vapors is the clearly enhanced proton concentration of aromatics and conjugated alkenes from $12 \%$ for $\mathrm{SiC}$ to $31.9 \%$ for oil obtained at $\mathrm{B}: \mathrm{C}=1.9-5.6$. The $\mathrm{H} \%$ of oxygenates and aliphatics (6-2 ppm) shows an inversely related trend and decreases from $62.7 \%(\mathrm{SiC})$ to $47.30 \%$ for $\mathrm{B}: \mathrm{C}=1.9-5.6$. The $\mathrm{H} \%$ of pine oil (from $\mathrm{SiC}$ bed) shows a higher contribution of carboxyl-groups compared to the straw oil, in agreement with a higher TAN of the former. In addition, carbonyl groups, phenols and aromatics show higher $\mathrm{H} \%$ compared to the wheat strawderived oil, which is likely the result of the elevated lignin content of wood (31.1 $\pm 0.8 \mathrm{wt} \%)$ compared to straw $(20.2 \pm 1.5 \mathrm{wt} \%)$. Table 5 provides the overview of the ${ }^{13} \mathrm{C}$ NMR characterization of the oils and the corresponding ${ }^{13} \mathrm{C}$ NMR spectra are provided in Fig. S6 and S7. It is noted that the C\% of the wood FP oil was calculated based on the ${ }^{13} \mathrm{C}$ NMR analysis of the three oils collected at the different condensation stages and their weight yields on dry basis. The pine derived $\mathrm{SiC}$ oil shows a higher $\mathrm{C}$ contribution of aldehydes, ketones, levoglucosan, anhydrosugars, alcohols, ethers, and lignin derived methoxyl-groups compared to the straw oil, which agrees with the higher oxygen content of the former. In agreement with the ${ }^{1} \mathrm{H}$ NMR results for the straw derived oils, the $\mathrm{C}$ content of aromatics (including olefins and phenols) increases from $36 \%(\mathrm{SiC})$ to $56.9 \%$ for B:C $=1.9-5.6$. Enhanced phenol yields besides aromatics for HZSM-5 based catalysts were also observed by others 39 and agrees with our GCMS/FID results, especially for oil obtained at B:C $=1.9-5.6$ (Table S5). Phenols were pointed out to have low reactivity and may strongly adsorb to the active sites on HZSM-5 and contribute to coke formation [42, 43]. The $\mathrm{C}$ content of the oils associated with oxygenates (220-160 ppm and 105-55 ppm) decreased from $27.6 \%$ to $9.3 \%$ for $\mathrm{B}: \mathrm{C}=1.9-5.6$. This observation is further confirmed by 2D HSQC NMR (see Fig. S8), which shows that especially sugars and -CHO- groups are still effectively converted over the pre-coked HZSM-5 extrudates $(\mathrm{B}: \mathrm{C}=1.9-5.6)$. 
Table 4. Hydrogen percentage based on the ${ }^{1} \mathrm{H}$ NMR analysis of the bio-oils.

\begin{tabular}{|c|c|c|c|c|}
\hline Assignment & $\begin{array}{l}\text { Chemical shift } \\
\text { range (ppm) }\end{array}$ & Pine, SiC & Straw, SiC & $\begin{array}{c}\text { Straw, Extr-st-u, } \\
\text { B:C }=1.9-5.6\end{array}$ \\
\hline$-\mathrm{COOH}$ & $12.5-11.0$ & $1.0 \%$ & $0.2 \%$ & $0.1 \%$ \\
\hline$-\mathrm{CHO}, \mathrm{ArOH}$ & $11-8.2$ & $6.2 \%$ & $0.7 \%$ & $3.5 \%$ \\
\hline $\begin{array}{l}\text { Aromatics and } \\
\text { conjugated alkene } \mathrm{H}\end{array}$ & $8.2-6$ & $17.6 \%$ & $12.0 \%$ & $31.9 \%$ \\
\hline $\begin{array}{l}\text { Aliphatic } \mathrm{OH},-\mathrm{CH}=\mathrm{CH}-\text {, } \\
\mathrm{ArCH}_{2} \text {-OR }\end{array}$ & $6-4.2$ & $11.8 \%$ & $4.7 \%$ & $1.2 \%$ \\
\hline $\mathrm{RCH}_{2} \mathrm{O}-\mathrm{R}, \mathrm{CH}_{3} \mathrm{OR}$ & $4.2-3$ & $21.2 \%$ & $9.6 \%$ & $2.2 \%$ \\
\hline $\begin{array}{l}\text { Aliphatic } \mathrm{H},-\mathrm{CHR}-\mathrm{C}=\mathrm{O} \text {, } \\
-\mathrm{CHR}-\mathrm{C}=\mathrm{C}\end{array}$ & $3.0-2.0$ & $20.8 \%$ & $48.4 \%$ & $43.9 \%$ \\
\hline Aliphatic $\mathrm{H}$ & $2.0-0$ & $21.4 \%$ & $24.6 \%$ & $17.2 \%$ \\
\hline
\end{tabular}

Table 5. Carbon percentage based on the ${ }^{13} \mathrm{C}$ NMR analysis of the bio-oils.

\begin{tabular}{lcccc}
\hline Assignment & $\begin{array}{c}\text { Chemical shift } \\
\text { range (ppm) }\end{array}$ & Pine, SiC & Straw, SiC & $\begin{array}{c}\text { Straw, Extr-st-u, } \\
\text { B:C }=1.9-5.6\end{array}$ \\
\hline $\begin{array}{l}\text { Aldehydes, ketones } \\
\text { CO groups (carboxylic }\end{array}$ & $220-180$ & $8.4 \%$ & $7.8 \%$ & $4.2 \%$ \\
$\begin{array}{l}\text { acids and derivatives) } \\
\text { Total Ar including olefins }\end{array}$ & $180-160$ & $6.6 \%$ & $7.6 \%$ & $2.2 \%$ \\
$\begin{array}{l}\text { and phenolics } \\
\text { Carbons in aromatic HC } \\
\text { further from an O atom }\end{array}$ & $160-105$ & $40.1 \%$ & $36.0 \%$ & $56.9 \%$ \\
$\begin{array}{l}\text { Levoglucosan, anhydrosugars, } \\
\text { alcohols, ethers }\end{array}$ & $105-60$ & $15.4 \%$ & $8.3 \%$ & $28 \%$ \\
& & & & \\
Methoxyl-group in lignin & $57-55$ & $4.4 \%$ & $3.9 \%$ & $2.5 \%$ \\
Aliphatic hydrocarbons & $55-0$ & $25.1 \%$ & $36.4 \%$ & $33.7 \%$ \\
\hline
\end{tabular}

\subsection{Results Co-processing Bio-oils with FCC Feed}

Fig. 2 shows the conversion of the different bio-oils mixed with the reference feed at increasing cat/oil ratios. The conversion for co-processing of the catalyt- 
ically upgraded pyrolysis oil was significantly lower than when the reference oil was processed alone. Without catalytic upgrading, the conversion was higher than or similar to the reference oil, and the pyrolysis oil originating from wheat straw and pine wood showed similar conversion behavior.



Fig. 2. Conversion from co-processing of bio-oil at different catalyst/oil ratios.

Table 6 compares the product yields from co-processing of the different biooils in the MAT at a fixed conversion of $77.5 \%$. The pine pyrolysis oil showed similar yields to the reference oil. Compared with the reference oil, the wheat straw pyrolysis oil without catalytic treatment gave a higher coke yield and correspondingly a lower LPG yield. For the catalytically treated wheat straw pyrolysis oil, this effect was even higher, resulting in an even higher coke yield and lower LPG yield (Table 6). This result seems surprising at first considering the lower MW, higher volatility, reduced oxygen content, and higher EHI of the upgraded oil compared to the raw wheat straw oil. However, the observations can be reasoned based on the higher concentration of aromatics, phenolics and nitrogen containing compounds for the partly deoxygenated oil obtained derived from using HZSM-5 based catalyst for vapor deoxygenation, as will be elaborated in the discussion (Section 4). 
Table 6. Yield comparison from MAT at constant conversion of $77.5 \%$.

\begin{tabular}{|c|c|c|c|c|}
\hline & Reference oil & Pine, SiC & Straw, SiC & $\begin{array}{c}\text { Straw, Extr-st-u, } \\
\text { B:C }=1.9-5.6\end{array}$ \\
\hline \multirow[t]{2}{*}{ Catalyst/oil } & 3.1 & 2.7 & 2.6 & 3.7 \\
\hline & \multicolumn{4}{|c|}{ Yields (wt\%) } \\
\hline $\mathrm{CO}$ & 0.16 & 0.38 & 0.27 & 0.25 \\
\hline $\mathrm{CO}_{2}$ & 0.47 & 0.54 & 0.51 & 0.49 \\
\hline Hydrogen & 0.51 & 0.38 & 0.4 & 0.51 \\
\hline $\mathrm{C}_{1}+\mathrm{C}_{2}$ & 3.6 & 3.9 & 4 & 3.9 \\
\hline LPG & 16 & 16 & 14.8 & 14.1 \\
\hline Naphtha & 45.1 & 45.2 & 44.2 & 44 \\
\hline $\mathrm{LCO}$ & 14.2 & 14.3 & 14.3 & 14.3 \\
\hline $\mathrm{HCO}$ & 8.3 & 8.2 & 8.2 & 8.2 \\
\hline Coke & 11.7 & 11.1 & 13.3 & 14.3 \\
\hline
\end{tabular}

Commercially, FCC units are often operated at constant coke generation and a comparison of the MAT results at constant coke yield thus can be more realistic. Compared with the reference oil at constant coke yield $(11.7 \mathrm{wt} \%)$, the wheat straw pyrolysis oil without catalytic treatment gave a lower conversion and thus higher yields of LCO and HCO, and a corresponding lower LPG yield (see Table 7). For the catalytically treated wheat straw FP oils, this effect was even higher, i.e. an even lower conversion and higher yields of LCO and HCO, and lower LPG yields. Fig. 3 shows the yield of dry gas, which is defined as the sum of $\mathrm{C}_{1}+\mathrm{C}_{2}$ hydrocarbons and hydrogen. All pyrolysis oils gave higher dry gas yields than the reference oil. The pine pyrolysis oil gave a higher dry gas yield than the wheat straw pyrolysis oils, and there was no significant effect of the catalytic treatment of the wheat straw pyrolysis oil on the total dry gas yield. Considering the hydrogen yields (Fig. 3b), the two pyrolysis oils without catalytic treating gave similar hydrogen yields, lower than the reference oil. The catalytically treated wheat straw pyrolysis oil gave similar hydrogen yields as 
Table 7. Yield comparison from MAT at fixed coke yield of $11.7 \mathrm{wt} \%$.

\begin{tabular}{lcccc}
\hline & Reference oil & Pine, SiC & Straw, SiC & $\begin{array}{c}\text { Straw, Extr-st-u, } \\
\text { B:C }=1.9-5.6\end{array}$ \\
\hline Conversion & 77.5 & 77.9 & 75.1 & 74.2 \\
catalyst/oil & 3.1 & 2.9 & 2 & 3 \\
\hline & & \multicolumn{2}{c}{ Yields $($ wt\%) } & \\
\hline CO & 0.16 & 0.33 & 0.18 & 0.2 \\
CO 2 & 0.47 & 0.57 & 0.46 & 0.43 \\
Hydrogen & 0.51 & 0.4 & 0.34 & 0.43 \\
$\mathrm{C}_{1}+\mathrm{C}_{2}$ & 3.6 & 4.2 & 3.6 & 3.3 \\
LPG & 16 & 16.4 & 13.7 & 12.9 \\
Naphtha & 45.1 & 44.3 & 45.1 & 45.1 \\
LCO & 14.2 & 14.2 & 15.7 & 16.1 \\
HCO & 8.3 & 7.9 & 9.2 & 9.7 \\
\hline
\end{tabular}

the reference oil. This agrees with higher values of $\mathrm{H} / \mathrm{C}$ and $\mathrm{EHI}$ of the partly deoxygenated oil compared to the raw FP oils. All the pyrolysis oils tested gave significantly higher yields of CO than the reference oil (Fig. 3r). The pine pyrolysis oil gave higher CO yield than the wheat straw pyrolysis oils, as expected from its higher O-content. The same effect could also be observed for $\mathrm{CO}_{2}$, but less pronounced (Fig. 3d). 

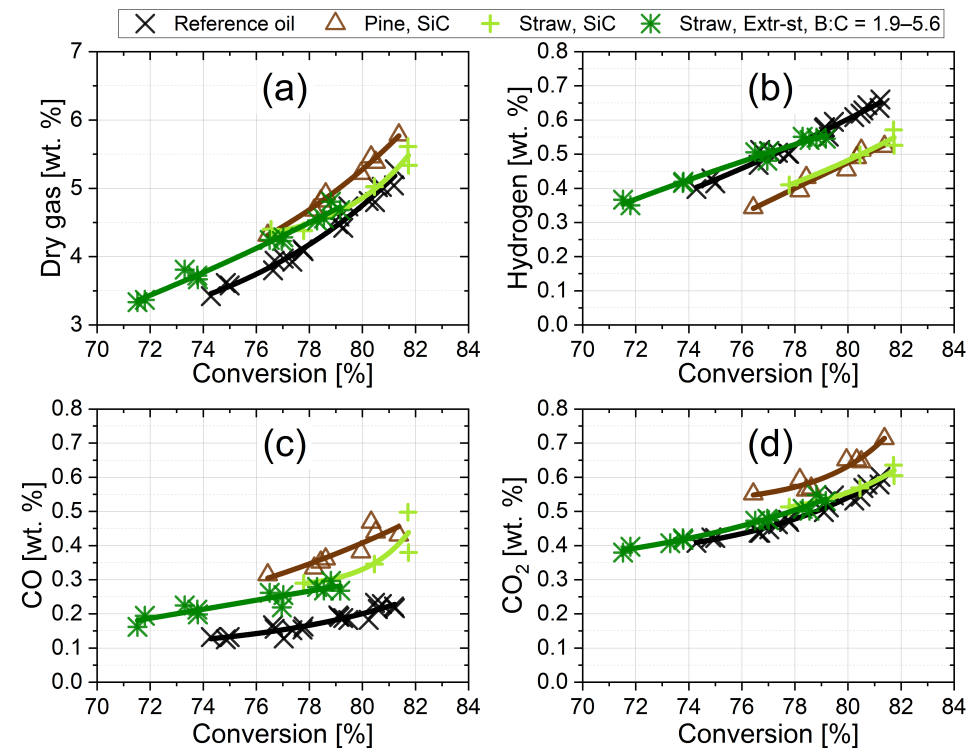

Fig. 3. Yields of gas species for reference oil and 80/20 blend with different bio-oils.

(a) Yields of dry gas, that is $\mathrm{C}_{1}+\mathrm{C}_{2}$ hydrocarbons plus hydrogen, (b) Hydrogen yields,

(c) $\mathrm{CO}$ yields, and (d) $\mathrm{CO}_{2}$ yields.

The pine pyrolysis oil gave similar LPG-yields as the reference oil. The wheat straw pyrolysis oils gave lower LPG yields, whereas the catalytically treated wheat straw pyrolysis oil gave the lowest LPG-yield (see Fig. 4 4 ). The $\mathrm{C}_{3}$ and $\mathrm{C}_{4}$ olefinicity of LPG is defined as the ratio of propene to total $\mathrm{C}_{3}$ and the ratio of butene to total $\mathrm{C}_{4}$, respectively. The pyrolysis oils gave higher LPG olefinicity than the reference oil. (Fig. $4 \mathrm{~b}+\mathrm{c})$. The effect was especially pronounced in the $\mathrm{C}_{4}$ fraction (Fig. 4 ). No significant difference between the wheat straw pyrolysis oil and the pine pyrolysis oil could be observed, but the catalytically treated wheat straw pyrolysis oil gave an even higher LPG olefinicity. 

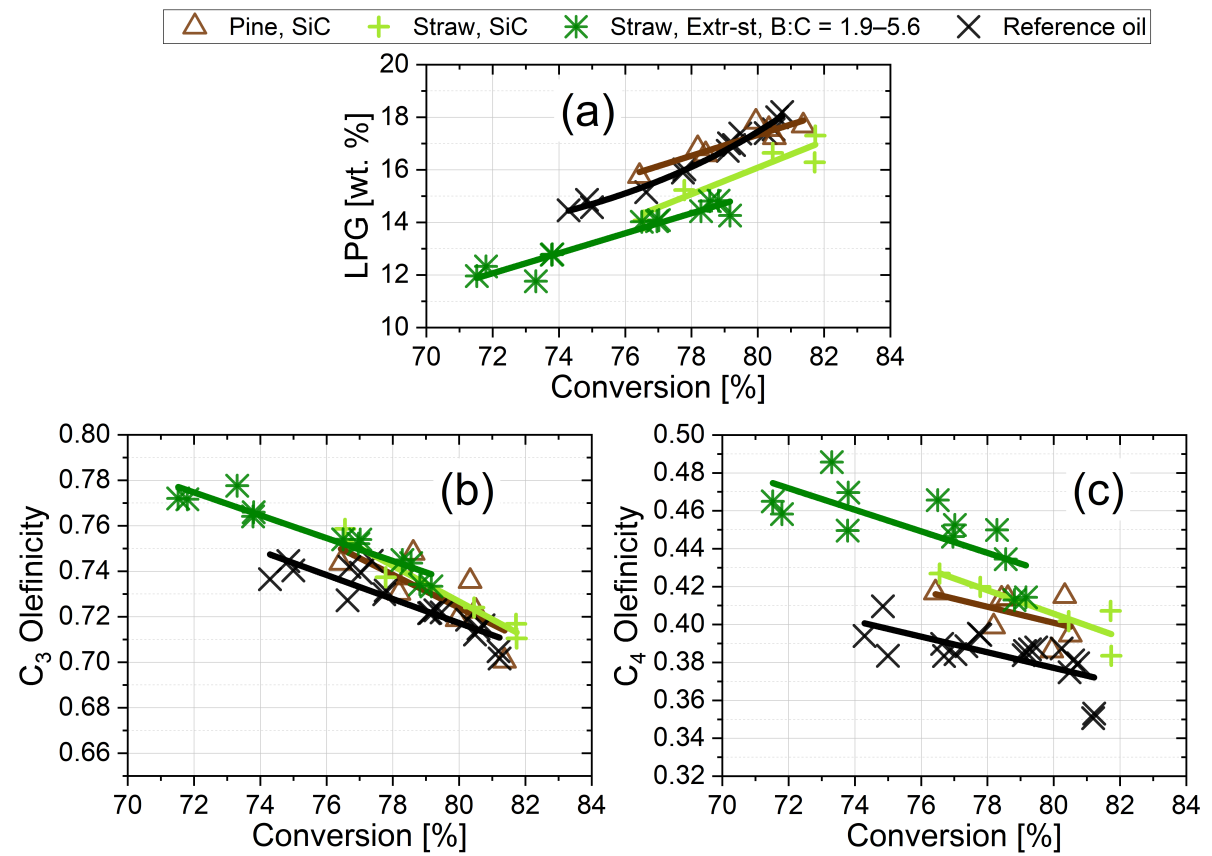

Fig. 4. (a) Yields of LPG $\left(\mathrm{C}_{3}+\mathrm{C}_{4}\right)$ when processing reference oil and 80/20 blends of reference oil with different bio-oils. (b) and (c) show the LPG olefinicity for $\mathrm{C}_{3}$ and $\mathrm{C}_{4}$ (b), which is is defined as the ratio of propene to total $\mathrm{C}_{3}$ and the ratio of butene to total $\mathrm{C}_{4}$, respectively.

Only small differences could be observed for LCO $\left(221-350{ }^{\circ} \mathrm{C}\right)$ and $\mathrm{HCO}$ $\left(350^{\circ} \mathrm{C}+\right)$ for the different oils tested (see Fig. 5). The processing of blends of pyrolysis oil and reference oil resulted in lower naphtha yields $\left(\mathrm{C}_{5}-221^{\circ} \mathrm{C}\right)$ compared to processing of $100 \%$ reference oil (see Fig. 6a). The pine pyrolysis oil gave a slightly higher naphtha yield than the wheat straw pyrolysis oils, and there was no significant effect of the catalytic treatment of the wheat straw pyrolysis oil on the naphtha yield during co-processing. Note that the experimental points were obtained in the over-cracking region, where the naphtha yield decreases with increasing conversion. Fig. $6 \mathrm{~b}$ shows a comparison of the coke yields. The wheat straw pyrolysis oils with and without catalytic treatment gave higher coke yields than the reference oil. The pine pyrolysis oil gave similar coke yield as the reference oil. 

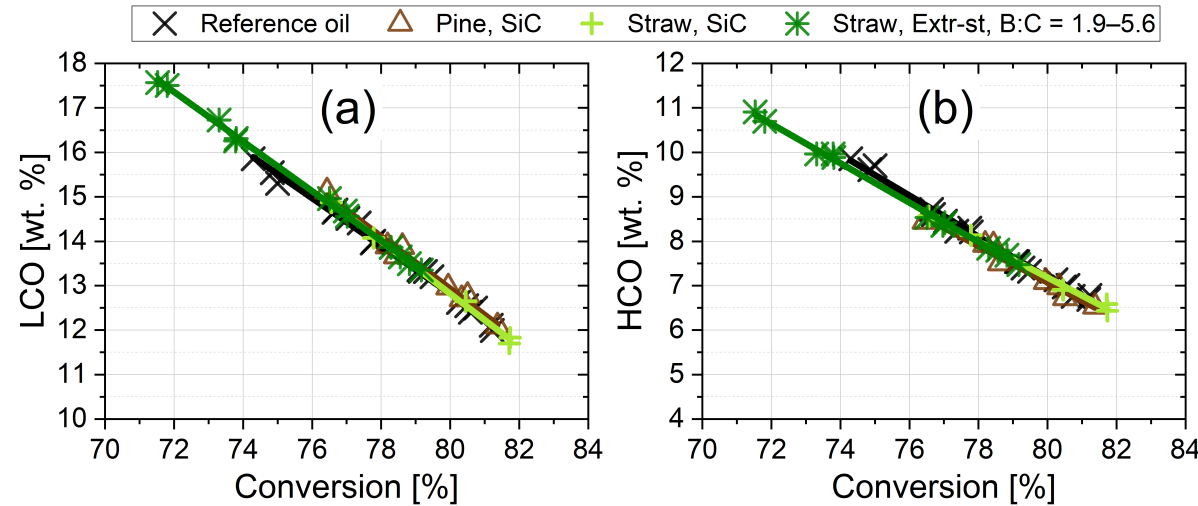

Fig. 5. (a) Yields of $\operatorname{LCO}\left(221-350{ }^{\circ} \mathrm{C}\right)$ and (b) Yields of $\mathrm{HCO}\left(350{ }^{\circ} \mathrm{C}+\right)$ for the different oils tested.

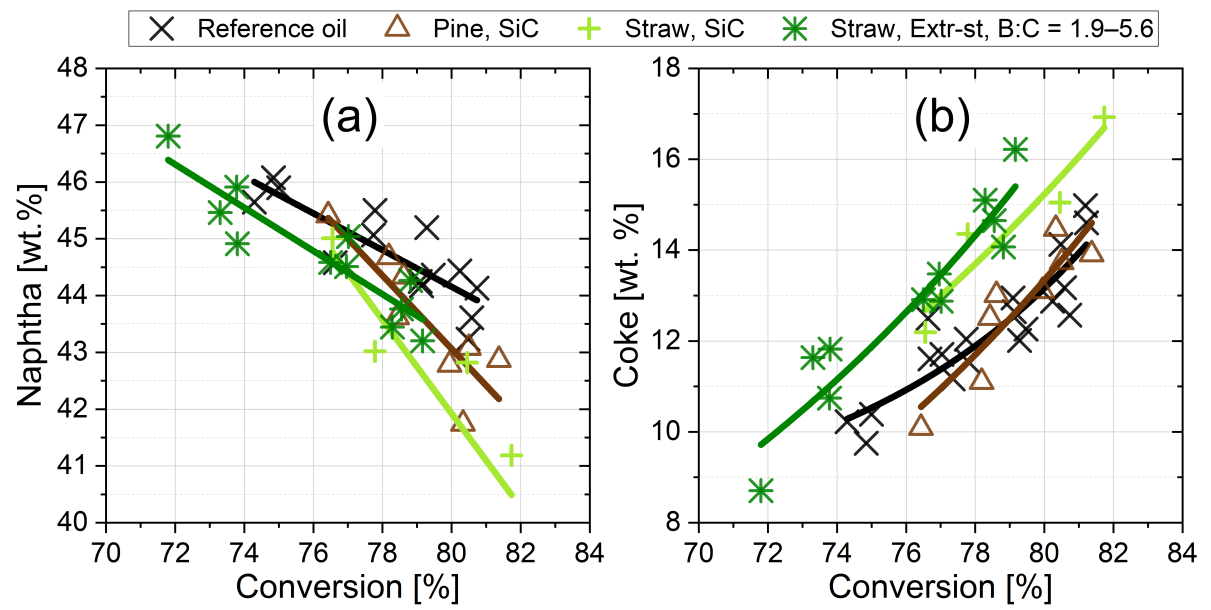

Fig. 6. Yields of naphtha (a) and coke (b) when processing reference oil and 80/20 blends of reference oil with different bio-oils in the MAT.

\section{Discussion}

A rough calculation indicates that at $80 \%$ conversion, the coke yield was about $28 \mathrm{wt} \%$ from the wheat straw bio-oils, indicating that a significant amount of biogenic carbon was lost to coke on the FCC catalyst. 
While water was not analyzed for in the products from these tests, the blending of the FCC reference feed with bio-oil introduced water in the feed and additional water may be formed during catalytic cracking of pyrolysis oils. In general, the influence of this on the results is minor compared to the mass balances uncertainty, as discussed in detail in the SI, Tables S6 and S7. However, the corrected yield for naphtha could be about 6 percentage points lower for the blends with raw FP oils due to their higher moisture content and possibly higher yield of cracking water by oxygen removal via dehydration, while it could only be about 2 percentage points lower for the blends with catalytic fast pyrolysis oil. Taking into account these considerations, it can be concluded that for the interpretation of the naphtha yields (Fig. 6a) all blends with bio-oils resulted in lower naphtha yields compared to processing of 100\% reference oil. In addition, it is possible that the blends with untreated wood and straw FP oils produced less naphtha compared to the catalytically treated FP oil.

Untreated pyrolysis oils have a very high TAN number (>50 mg $\mathrm{KOH} / \mathrm{g}$ ), which can cause severe corrosion in commercial operation 44]. The TAN of pyrolysis oils is effectively reduced by catalytic upgrading of the vapors prior to condensation, however, the oil yield decreases with the severity of the vapor deoxygenation. Mild deoxygenation of the pyrolysis vapor over a pre-coked HZSM-5 $/ \mathrm{Al}_{2} \mathrm{O}_{3}$ catalyst, as applied in this work, obtained higher bio-oil yields compared to upgrading over a fresh catalyst due to the reduced carbon losses to gas and coke, while the TAN of the obtained oil (3.4 mg $\mathrm{KOH} / \mathrm{g})$ was still considerably lowered compared to the raw FP oil 31, 32]. The TAN-number for the reference feed used in this study was not measured, but based on TANnumbers for other North Sea atmospheric resids, the value is assumed to be close to $1 \mathrm{mg} \mathrm{KOH} / \mathrm{g}$. Assuming a maximum allowable TAN for the blended feed of $\sim 2 \mathrm{mg} \mathrm{KOH} / \mathrm{g}$ in order to prevent corrosion of the FCC plant, the residual acidity of the pyrolysis oil could then be accommodated by diluting with crude oil or an internal refinery stream (naphtha, gas oil, etc.) [12]. Thus, for untreated wood and straw bio-oils the blend ratio would have to be limited to 1-2 wt\% bio-oil, while up to $\sim 40$ wt $\%$ could be blended in the case of the catalytically upgraded oil. 
On the other hand, $39 \%$ of the energy of the wheat straw FP oil was lost by the pre-cracking, and the conversion of the blend with deoxygenated oil in the subsequent MAT tests was lower compared to the raw bio-oil. This indicates that HZSM-5 based catalysts may not be the optimal choice for this application. HZSM-5 is well known for its high aromatization activity and lower coke yields compared to other zeolites. However, besides monoaromatics also higher concentrations of phenols and nitrogen-containing compounds were observed in the product mixture, and all three product groups may negatively affect the conversion when added to an FCC feedstock [45. Once the deoxygenation activity of HZSM-5 decreases, more oxygen and nitrogen appears to be retained in the hydrocarbon pool, leading to the formation of hetero-aromatics with nitrogen and oxygen [46. In catalytic cracking, aromatic rings are difficult to crack and tend to polymerize and form coke. In addition, phenolic molecules can have a detrimental impact on the zeolite component of FCC catalysts 47, 48. The deoxygenated oil contained higher concentrations of aromatics (1-3 rings) and the concentration of phenolics determined by GC-MS/FID was 6.5 times higher compared to oil obtained over $\mathrm{SiC}[32$. Since the deoxygenated oil was collected at $\mathrm{B}: \mathrm{C}=1.9-5.6$, it is very likely that the production of phenolics was particularly favored in this range as opposed to $\mathrm{B}: \mathrm{C}<1.9$ or operation to very high $\mathrm{B}: \mathrm{C}$ ratios which would approach the composition of the $\mathrm{SiC}$ oil.

Basic nitrogen is a well-known catalyst poison in catalytic cracking [49 51]. Decreased gasoline yields and increased hydrogen yields (compared at constant conversion) were observed by Caeiro et al. [50] for increasing feedstock basic nitrogen content. For conventional refinery feedstock, the content of basic nitrogen is usually about one third of the total nitrogen $51+53$. The basic nitrogen content of the wheat straw oils obtained with $\mathrm{SiC}$ and $\mathrm{HZSM}-5 / \mathrm{Al}_{2} \mathrm{O}_{3}$ was 3920 and $5670 \mathrm{ppm}$, which is less than one third of the total nitrogen content of the oils (see Table 3 but still considerably higher compared to the basic nitrogen content of the reference feed $(620 \mathrm{ppm})$. Basic nitrogen compounds may reduce the cracking activity by (i) site competition due to their reversible adsorption to Brønsted and Lewis acid sites, and (ii) acting as coke precursors due to their size and aromatic nature. The nitrogen content of the severely deoxygenated 
oil collected at $\mathrm{B}: \mathrm{C}=1.9$ with $2.9 \mathrm{wt} \% \mathrm{O}$ and $6.6 \mathrm{wt} \% \mathrm{C}$ recovery was only $1.5 \mathrm{wt} \%$, while the oil collected at $\mathrm{B}: \mathrm{C}=1.9-5.6$ had increased carbon recovery of $17.1 \mathrm{wt} \%$ but contained $3.6 \mathrm{wt} \%$ N. Analysis by GC-MS/FID indicated that methyl- and dimethyl-pyridine, as well as dimethyl-indazole are amongst the highest concentrated nitrogen compounds in the oil collected at $\mathrm{B}: \mathrm{C}=1.9-$ 5.6 and the concentration of $\mathrm{N}$ containing compounds was about twice as high compared to the non-catalytically treated wheat straw oil and the oil collected at $\mathrm{B}: \mathrm{C}=0-1.9$ over HZSM-5 $/ \mathrm{Al}_{2} \mathrm{O}_{3}$. With increasing catalyst deactivation, a shift to higher MW compounds occurred which lie outside the identification range of the applied gas chromatography method. While non-basic nitrogen compounds and condensed aromatics contribute to coke formation on the external surface of zeolite crystallites and pore blockage [54, the poisoning ability of bulkier nitrogen bases is even higher [52, 55]. Xu et al. [56 60] demonstrated that N-heterocycles (pyridines, pyrroles, anilines and indoles) can be produced via reaction of biomass derived oxygenates and ammonia. Even though not measured directly, some ammonia may be produced from the FP of wheat straw containing $\sim 1 \mathrm{wt} \% \mathrm{~N}$ (d.b.) and lead to the formation of N-heterocycles.

The present results agree with Stefanidis et al.'s review 17] indicating that most studies that investigated co-processing of bio-oil found decreased naphtha yields. Lower hydrogen yields compared to the reference feed upon co-feeding of untreated pyrolysis oils were also observed by others [4, 15, 22, 25, 61]. Increased coke yields upon co-feeding of both raw and CFP oils agrees with Lindfors et al.s work [19], who tested CFP oil (22 wt\% O) at the same blending ratio as this study $(20 / 80)$, however at lower conversions (30-41\%). It should be noted that lab scale co-processing of bio-oils to FCC units may overestimate the coke yields 15 , 62. In contrast to larger operation scale, a thermal shock between the hot catalyst and the bio-oil is not possible at laboratory scale and the non-vaporized fraction of the bio-oil will yield more char/coke upon reheating [22]. The thermal shock allows to break high MW compounds in larger scale units and improves the accessibility to the micropores of the catalyst [26]. This was confirmed by Wang et al. 4] who attributed their good results in terms of almost complete oxygen removal during FFC co-processing to the larger operating scale and the 
benefits of thermal shock effect in their pilot-scale unit. Several researchers have investigated FCC of upgraded FP oils mixed with crude oil distillates in MAT units 26, 63 65. While co-refining may lead to severe changes in product quality, such as a higher aromaticity and residual oxygenates in the hybrid fuels that are produced, it was concluded that a compromise can be reached between bio-oil upgrading severity and FCC product yields and quality.

To allow processing in FCC, the oils oxygen and nitrogen content has to be taken into account as they affect plant corrosion and FCC catalyst deactivation. While the reduced TAN and polarity of the deoxygenated oil will allow higher blend ratios compared to untreated bio-oil considering corrosion and miscibility, the current study shows that the basic nitrogen content has to be taken into account as well since it affects FCC catalyst deactivation. Thus, catalytically treated wheat straw oil obtained with HZSM-5 based catalysts may require further hydrotreating prior to FCC in order to saturate condensed aromatics, remove phenols and reduce the content of basic nitrogen [51, 66. While it is desirable to develop a nitrogen-resistant FCC catalyst [50, 67, 69, the nitrogen poisoning is reversible, as the nitrogen components are burned in the FCC regenerator (see Peng et al. 45], and references therein).

Mild upgrading by cracking increases the energy recovery of bio-oil compared to deep deoxygenation 32 . Higher coke yields upon co-feeding of bio-oil may be tolerable to some extent as the oxidative regeneration generates the energy required to run the endothermic cracking process [70; however, increased coke yields in combination with lower conversion as was observed for blends with catalytically deoxygenated wheat straw oil indicates a less desirable FCC performance.

\section{Conclusion}

Two untreated fast pyrolysis oils from pine and wheat straw and a catalytically treated wheat straw fast pyrolysis oil were blended in a 20/80 ratio with FCC reference feed oil and tested in a MAT containing a partly deactivated 
FCC catalyst. Fast pyrolysis oil from pine performed best as it resulted in similar product and coke yields compared to the reference oil. The conversion of blends with untreated oils from pine and wheat straw was higher compared to the reference oil, however, blends with the wheat straw oil resulted in higher coke and lower LPG yields. Catalytically upgraded straw pyrolysis oil gave an even higher coke yield and lower LPG yield and resulted in lower conversions compared to the reference oil. All the pyrolysis oils gave lower naphtha yield than the reference oil and the pine pyrolysis oil gave a slightly higher naphtha yield compared to the straw oils. The study shows that not only wood derived pyrolysis oils but also pyrolysis oils obtained from agricultural residues such as wheat straw could contribute to the refinery input stream. However, the reduction of the TAN via deoxygenation of wheat straw fast pyrolysis vapors over HZSM-5 $/ \mathrm{Al}_{2} \mathrm{O}_{3}$ increased the nitrogen concentration of the stabilized oil, which in turn had a poisoning effect on the FCC catalyst. The basic nitrogen content of fast pyrolysis oils produced from agricultural residues with elevated nitrogen content shall thus be taken into account during the catalyst optimization for deoxygenation of fast pyrolysis vapors.

\section{ASSOCIATED CONTENT}

\section{Supporting Information}

$\mathrm{NH}_{3}$-TPD of HZSM-5 extrudate; Moisture content, HHV and elemental analysis of oil and aqueous fractions; TGA simulated distillation curves; Size exclusion chromatograms; molar $\mathrm{H} / \mathrm{C}$ ratio and $\mathrm{O} / \mathrm{C}$ ratio of oils; ${ }^{1} \mathrm{H} \mathrm{NMR}$ and ${ }^{13} \mathrm{C}$ NMR spectra; HSQC NMR spectra; yields obtained by GC-MS/FID analysis.

\section{AUTHOR INFORMATION}

\section{Corresponding Author}

Anker Degn Jensen (aj@kt.dtu.dk)

\section{Funding Sources}

Partial funding by the Energy Technology Development and Demonstration Program (EUDP project number 12454) of the $\mathrm{PhD}$ project conducted at the CHEC Research Center, DTU Chemical Engineering is acknowledged. 


\section{ACKNOWLEDGMENT}

The authors would like to thank Ingunn Tanem (Equinor Marketing, Midstream and Processing, Arkitekt Ebbels veg 10, 7053 Ranheim, Norway) for conducting the MAT-tests. Lotte Nielsen and Sokol Ndoni (DTU Department of Micro- and Nanotechnology, Denmark) are acknowledged for the oil analysis by size exclusion.

\section{ABBREVIATIONS}

BET, Brunauer-Emmett-Teller; CFP, catalytic fast pyrolysis; CPS, cyclic propylene steaming; daf, dry and ash-free basis; d.b., dry basis; HCO; heavy cycle oil; FCC, Fluid Catalytic Cracking; GC-MS/FID, gas chromatography mass spectrometry with flame ionization detection; HHV, higher heating value; LCO, light cycle oil; LPG, liquid petroleum gas; MW, molecular weight; NMR, nuclear magnetic resonance; SEC, size exclusion chromatography; TAN, total acid number; TGA, thermogravimetric analysis; OF, oil fraction; VGO, vacuum gas oil; WF, water fraction;

\section{References}

[1] G. W. Huber, A. Corma, Synergies between bio- and oil refineries for the production of fuels from biomass, Angewandte Chemie - International Edition 46 (38) (2007) 7184-7201. doi:10.1002/anie.200604504.

[2] N. Tröger, D. Richter, R. Stahl, Effect of feedstock composition on product yields and energy recovery rates of fast pyrolysis products from different straw types, J. Anal. Appl. Pyrolysis 100 (2013) 158-165. doi:10.1016/ j.jaap.2012.12.012

[3] C. W. Edmunds, E. A. R. Molina, N. Andre, C. Hamilton, S. Park, O. Fasina, S. Adhikari, S. S. Kelley, J. S. Tumuluru, T. G. Rials, N. Labbe, Blended Feedstocks for Thermochemical Conversion: Biomass Characterization and Bio-Oil Production From Switchgrass-Pine Residues Blends, Front. Energy Res. 6 (August) (2018) 16. doi:10.3389/fenrg.2018. 
00079

[4] C. Wang, M. Li, Y. Fang, Coprocessing of Catalytic-Pyrolysis-Derived BioOil with VGO in a Pilot-Scale FCC Riser, Ind. Eng. Chem. Res. 55 (12) (2016) 3525-3534. doi:10.1021/acs.iecr.5b03008

[5] D. L. Carpenter, T. L. Westover, S. Czernik, W. Jablonski, Biomass feedstocks for renewable fuel production: a review of the impacts of feedstock and pretreatment on the yield and product distribution of fast pyrolysis bio-oils and vapors, Green Chem. 16 (2) (2014) 384-406. doi: 10.1039/C3GC41631C

[6] B. Rejai, S. C. S. C. Engineer, R. J. Evans, S. Chemist, P. Chemist, J. P. Diebold, P. C. Engineer, J. W. Scahill, S. C. S. C. Engineer, C. Conversion, The conversion of biobased feedstocks to liquid fuels through pyrolysis, in: Energy From Biomass and Wastes Xv, INST GAS TECHNOLOGY, 1991, pp. $855-876$.

[7] T. N. Trinh, P. A. Jensen, D. J. Kim, N. O. Knudsen, H. R. Sørensen, S. Hvilsted, Comparison of lignin, macroalgae, wood, and straw fast pyrolysis, Energy Fuels 27 (3) (2013) 1399-1409. doi:10.1021/ef301927y.

[8] C. E. Greenhalf, D. J. Nowakowski, A. B. Harms, J. O. Titiloye, A. V. Bridgwater, A comparative study of straw, perennial grasses and hardwoods in terms of fast pyrolysis products, Fuel 108 (2013) 216-230. doi: $10.1016 / \mathrm{j}$. fuel.2013.01.075.

[9] A. V. Bridgwater, G. V. C. Peacocke, Fast pyrolysis processes for biomass, Renewable \& Sustainable Energy Reviews 4 (1) (2000) 1-73. doi:10.1016/ S1364-0321(99)00007-6.

[10] A. Oasmaa, S. Czernik, Fuel oil quality of biomass pyrolysis oil - State of the art for the end users, Energy \& Fuels 13 (4) (1999) 914-921. doi: $10.1021 /$ ef $980272 b$ 
[11] S. Czernik, A. V. Bridgwater, Overview of applications of biomass fast pyrolysis oil, Energy \& Fuels 18 (2) (2004) 590-598. doi:10.1021/ef034067u

[12] M. S. Talmadge, R. M. Baldwin, M. J. Biddy, R. L. McCormick, G. T. Beckham, G. A. Ferguson, S. Czernik, K. A. Magrini, T. D. Foust, P. D. Metelski, C. Hetrick, M. R. Nimlos, A perspective on oxygenated species in the refinery integration of pyrolysis oil, Green Chem. 16 (2) (2014) 407-453. doi:10.1039/C3GC41951G.

[13] R. French, S. Czernik, Catalytic pyrolysis of biomass for biofuels production, Fuel Process. Technol. 91 (1) (2010) 25-32. doi:10.1016/j.fuproc. 2009.08.011.

[14] K. Maniatis, L. Waldheim, S. Kalligeros, Final Report Building Up the Future Sub Group on Advanced Biofuels Sustainable Transport Forum, 2017.

[15] A. d. R. Pinho, M. B. de Almeida, F. L. Mendes, L. C. Casavechia, M. S. Talmadge, C. M. Kinchin, H. L. Chum, Fast pyrolysis oil from pinewood chips co-processing with vacuum gas oil in an FCC unit for second generation fuel production, Fuel 188 (2017) 462-473. doi:10.1016/j.fuel. 2016.10 .032

[16] T. Marker, J. Petri, T. Kalnes, M. McCall, D. Mackowiak, B. Jerosky, B. Reagan, L. Nemeth, M. Krawczyk, S. Czernik, D. C. Elliott, D. Shonnard, Opportunities for Biorenewables in Oil Refineries, Tech. rep., Golden Field Office, Golden, CO (dec 2005). doi:10.2172/861458,

URL http://www.osti.gov/servlets/purl/861458-Wv5uum/

[17] S. D. Stefanidis, K. G. Kalogiannis, A. A. Lappas, Co-processing bio-oil in the refinery for drop-in biofuels via fluid catalytic cracking, Wiley Interdisciplinary Reviews: Energy and Environment (October) (2017) e281. doi:10.1002/wene.281. 
[18] M. Bertero, U. Sedran, Coprocessing of Bio-oil in Fluid Catalytic Cracking, Recent Advances in Thermochemical Conversion of Biomass (2015) 355381doi:10.1016/B978-0-444-63289-0.00013-2.

[19] C. Lindfors, V. Paasikallio, E. Kuoppala, M. Reinikainen, A. Oasmaa, Y. Solantausta, Co-processing of dry bio-oil, catalytic pyrolysis oil, and hydrotreated bio-oil in a micro activity test unit, Energy Fuels 29 (6) (2015) 3707-3714. doi:10.1021/acs .energyfuels.5b00339.

[20] A. de Rezende Pinho, M. B. B. de Almeida, F. L. Mendes, V. L. Ximenes, Production of lignocellulosic gasoline using fast pyrolysis of biomass and a conventional refining scheme, Pure Appl. Chem. 86 (5). doi:10.1515/ pac-2013-0914.

[21] Á. Ibarra, E. Rodríguez, U. Sedran, J. M. Arandes, J. Bilbao, Synergy in the Cracking of a Blend of Bio-oil and Vacuum Gasoil under Fluid Catalytic Cracking Conditions, Ind. Eng. Chem. Res. 55 (7) (2016) 1872-1880. doi: 10.1021/acs.iecr.5b04502,

[22] A. D. R. Pinho, M. B. De Almeida, F. L. Mendes, V. L. Ximenes, L. C. Casavechia, Co-processing raw bio-oil and gasoil in an FCC Unit, Fuel Process. Technol. 131 (2015) 159-166. doi:10.1016/j.fuproc.2014.11. 008.

[23] S. Bezergianni, A. Dimitriadis, O. Kikhtyanin, D. Kubička, Refinery coprocessing of renewable feeds, Prog. Energy Combust. Sci. 68 (2018) 29-64. doi:10.1016/j.pecs.2018.04.002

[24] D. V. Naik, V. Kumar, B. Prasad, Pyrolysis Oil Upgrading to Fuels by Catalytic Cracking: A Refinery Perspective, in: Prospects of Alternative Transportation Fuels, 2018, pp. $269-295$.

[25] F. A. Agblevor, O. Mante, R. Mcclung, S. T. Oyama, Co-processing of standard gas oil and biocrude oil to hydrocarbon fuels, Biomass Bioenergy 45 (2012) 130-137. doi:10.1016/j.biombioe.2012.05.024. 
[26] N. Thegarid, G. Fogassy, Y. Schuurman, C. Mirodatos, S. D. Stefanidis, E. F. Iliopoulou, K. Kalogiannis, A. A. Lappas, Second-generation biofuels by co-processing catalytic pyrolysis oil in FCC units, Appl. Catal., B 145 (2014) 161-166. doi:10.1016/j.apcatb.2013.01.019.

[27] L. Negahdar, A. Gonzalez-Quiroga, D. Otyuskaya, H. E. Toraman, L. Liu, J. T. B. H. Jastrzebski, K. M. Van Geem, G. B. Marin, J. W. Thybaut, B. M. Weckhuysen, K. M. V. Geem, G. B. Marin, J. W. Thybaut, B. M. Weckhuysen, Characterization and Comparison of Fast Pyrolysis Bio-oils from Pinewood, Rapeseed Cake, and Wheat Straw Using13C NMR and Comprehensive GC GC, ACS Sustainable Chemistry and Engineering 4 (9) (2016) 4974-4985. doi:10.1021/acssuschemeng.6b01329.

[28] A. Jensen, K. Dam-Johansen, M. A. Wójtowicz, M. A. Serio, TG-FTIR study of the influence of potassium chloride on wheat straw pyrolysis, Energy Fuels 12 (5) (1998) 929-938. doi:10.1021/ef980008i.

[29] K. Lazdovica, L. Liepina, V. Kampars, Comparative wheat straw catalytic pyrolysis in the presence of zeolites, $\mathrm{Pt} / \mathrm{C}$, and $\mathrm{Pd} / \mathrm{C}$ by using TGA-FTIR method, Fuel Process. Technol. 138 (2015) 645-653. doi: $10.1016 / \mathrm{j}$.fuproc.2015.07.005.

[30] N. Bech, M. B. Larsen, P. A. Jensen, K. Dam-Johansen, Modelling solidconvective flash pyrolysis of straw and wood in the Pyrolysis Centrifuge Reactor, Biomass Bioenergy 33 (6-7) (2009) 999-1011. doi:10.1016/j. biombioe.2009.03.009,

[31] A. Eschenbacher, P. A. Jensen, U. B. Henriksen, J. Ahrenfeldt, C. Li, J. Ø. Duus, U. V. Mentzel, A. D. Jensen, Impact of ZSM-5 deactivation on biooil quality during upgrading of straw derived pyrolysis vapors, Energy \& Fuels 33 (1) (2019) 397-412. doi:10.1021/acs.energyfuels.8b03691.

[32] A. Eschenbacher, P. A. Jensen, U. B. Henriksen, J. Ahrenfeldt, C. Li, J. Ø. Duus, U. V. Mentzel, A. D. Jensen, Deoxygenation of wheat 
straw fast pyrolysis vapors using HZSM-5, Al2O3 , HZSM-5/Al2O3 extrudates, and desilicated HZSM-5/Al2O3 extrudates, Energy \& Fuels (2019) acs.energyfuels.9b00906 doi : 10.1021/acs . energyfuels.9b00906.

[33] T. Myrstad, H. Engan, Testing of resid FCC catalysts in MAT, Appl. Catal., A 171 (1) (1998) 161-165. doi:10.1016/S0926-860X (98) 00100-8

[34] N. Y. Chen, D. E. Walsh, L. R. Koenig, Fluidized Bed Upgrading of Wood Pyrolysis Liquids and Related Compounds., ACS Division of Fuel Chemistry, Preprints 32 (2) (1987) 264-275. doi:10.1021/bk-1988-0376. ch024.

[35] S. A. Channiwala, P. P. Parikh, A unified correlation for estimating HHV of solid, liquid and gaseous fuels, Fuel 81 (8) (2002) 1051-1063. doi: 10.1016/S0016-2361(01)00131-4.

[36] A. V. Bridgwater, Review of fast pyrolysis of biomass and product upgrading, Biomass Bioenergy 38 (2012) 68-94. doi:10.1016/j.biombioe.2011. 01.048

[37] R. M. Baldwin, C. J. Feik, Bio-oil stabilization and upgrading by hot gas filtration, Energy Fuels 27 (6) (2013) 3224-3238. doi:10.1021/ef400177t.

[38] J. Sitzmann, Upgrading of Fast Pyrolysis Oils by Hot Filtration (2009) 135.

[39] E. F. Iliopoulou, S. D. Stefanidis, K. G. Kalogiannis, A. Delimitis, A. A. Lappas, K. S. Triantafyllidis, Catalytic upgrading of biomass pyrolysis vapors using transition metal-modified ZSM-5 zeolite, Appl. Catal., B 127 (2012) 281-290. doi:10.1016/j.apcatb.2012.08.030.

[40] V. Balasundram, N. Ibrahim, R. M. Kasmani, R. Isha, M. K. A. Hamid, H. Hasbullah, R. R. Ali, Catalytic upgrading of sugarcane bagasse pyrolysis vapours over rare earth metal $(\mathrm{Ce})$ loaded HZSM-5: Effect of catalyst to biomass ratio on the organic compounds in pyrolysis oil, Appl. Energy 220 (December 2017) (2018) 787-799. doi:10.1016/j.apenergy.2018. 03.141 
[41] M. Zhang, F. L. P. Resende, A. Moutsoglou, Catalytic fast pyrolysis of aspen lignin via Py-GC/MS, Fuel 116 (2014) 358-369. doi:10.1016/j. fuel.2013.07.128.

[42] K. Wang, K. H. Kim, R. C. Brown, Catalytic pyrolysis of individual components of lignocellulosic biomass, Green Chem. 16 (2) (2014) 727. doi:10.1039/c3gc41288a.

[43] C. A. Mullen, A. A. Boateng, Production of Aromatic Hydrocarbons via Catalytic Pyrolysis of Biomass over Fe-Modified HZSM-5 Zeolites, ACS Sustainable Chemistry and Engineering 3 (7) (2015) 1623-1631. doi:10. 1021/acssuschemeng. 5b00335.

[44] M. Brady, J. Keiser, D. Leonard, A. Zacher, K. Bryden, G. Weatherbee, Corrosion of stainless steels in the riser during co-processing of bio-oils in a fluid catalytic cracking pilot plant, Fuel Process. Technol. 159 (2017) 187-199. doi:10.1016/j.fuproc.2017.01.041.

[45] P. Bai, U. J. Etim, Z. Yan, S. Mintova, Z. Zhang, Z. Zhong, X. Gao, Fluid catalytic cracking technology: current status and recent discoveries on catalyst contamination, Catalysis Reviews - Science and Engineering 00 (00) (2018) 1-73. doi:10.1080/01614940.2018.1549011.

[46] A. R. Stanton, K. Iisa, C. Mukarakate, M. R. Nimlos, Role of Biopolymers in the Deactivation of ZSM-5 during Catalytic Fast Pyrolysis of Biomass, ACS Sustainable Chemistry and Engineering 6 (8) (2018) 10030-10038. doi:10.1021/acssuschemeng.8b01333.

[47] I. Graça, A. M. Carmo, J. M. Lopes, M. F. Ribeiro, Improving HZSM5 resistance to phenolic compounds for the bio-oils/FCC feedstocks coprocessing, Fuel 140 (2015) 484-494. doi:10.1016/j.fuel.2014.10.002

[48] I. Graca, J. M. Lopes, M. F. Ribeiro, F. R. Ribeiro, H. S. Cerqueira, M. B. B. D. Almeida, Catalytic cracking in the presence of guaiacol 101 (2011) 613-621. doi:10.1016/j.apcatb.2010.11.002. 
[49] G. A. Mills, E. R. Boedeker, A. G. Oblad, Chemical Characterization of Catalysts. I. Poisoning of Cracking Catalysts by Nitrogen Compounds and Potassium Ion, J. Am. Chem. Soc. 72 (4) (1950) 1554-1560. doi:10.1021/ ja01160a035

[50] G. Caeiro, A. F. Costa, H. S. Cerqueira, P. Magnoux, J. M. Lopes, P. Matias, F. R. Ribeiro, Nitrogen poisoning effect on the catalytic cracking of gasoil, Appl. Catal., A 320 (2007) 8-15. doi:10.1016/j.apcata.2006. 11.031 .

[51] Q. Sheng, G. Wang, Y. Liu, M. M. Husein, C. Gao, J. Gao, Pilot-scale evaluation of hydrotreating inferior coker gas oil prior to its fluid catalytic cracking, Fuel 226 (November 2017) (2018) 27-34. doi:10.1016/j.fuel. 2018.03 .150

[52] C. M. Fu, A. M. Schaffer, Effect of Nitrogen Compounds on Cracking Catalysts, Industrial and Engineering Chemistry Product Research and Development 24 (1) (1985) 68-75. doi:10.1021/i300017a013.

[53] X. Chen, Y. Liu, S. Li, X. Feng, H. Shan, C. Yang, Structure and Composition Changes of Nitrogen Compounds during the Catalytic Cracking Process and Their Deactivating Effect on Catalysts, Energy Fuels 31 (4) (2017) 3659-3668. doi:10.1021/acs .energyfuels.6b03230.

[54] Z. K. Li, J. S. Gao, G. Wang, Q. Shi, C. M. Xu, Influence of nonbasic nitrogen compounds and condensed aromatics on coker gas oil catalytic cracking and their characterization, Ind. Eng. Chem. Res. 50 (15) (2011) 9415-9424. doi:10.1021/ie2003973

[55] G. Caeiro, P. Magnoux, P. Ayrault, J. M. Lopes, F. R. Ribeiro, Deactivating effect of coke and basic nitrogen compounds during the methylcyclohexane transformation over H-MFI zeolite, Chemical Engineering Journal 120 (1-2) (2006) 43-54. doi:10.1016/j.cej.2006.03.036. 
[56] L. Xu, Q. Yao, Y. Zhang, Y. Fu, Integrated Production of Aromatic Amines and N-Doped Carbon from Lignin via ex Situ Catalytic Fast Pyrolysis in the Presence of Ammonia over Zeolites, ACS Sustainable Chemistry and Engineering 5 (4) (2017) 2960-2969. doi:10.1021/acssuschemeng. $6 \mathrm{~b} 02542$

[57] L. Xu, Y. Jiang, Q. Yao, Z. Han, Y. Zhang, Y. Fu, Q. Guo, G. W. Huber, Direct production of indoles via thermo-catalytic conversion of bio-derived furans with ammonia over zeolites, Green Chem. 17 (2) (2015) 1281-1290. doi:10.1039/c4gc02250e.

[58] L. Xu, Z. Han, Q. Yao, J. Deng, Y. Zhang, Y. Fu, Q. Guo, Towards the sustainable production of pyridines via thermo-catalytic conversion of glycerol with ammonia over zeolite catalysts, Green Chem. 17 (4) (2015) 2426-2435. doi:10.1039/c4gc02235a.

[59] L. Xu, Y. Zhang, Y. Fu, Advances in Upgrading Lignin Pyrolysis Vapors by ExSitu Catalytic Fast Pyrolysis, Energy Technology 5 (1) (2016) 30-51. doi:10.1002/ente.201600107.

[60] L. Xu, Q. Yao, J. Deng, Z. Han, Y. Zhang, Y. Fu, G. W. Huber, Q. Guo, Renewable N-Heterocycles Production by Thermocatalytic Conversion and Ammonization of Biomass over ZSM-5, ACS Sustainable Chemistry and Engineering 3 (11) (2015) 2890-2899. doi:10.1021/acssuschemeng. $5 \mathrm{~b} 00841$.

[61] K. Bryden, G. Weatherbee, E. T. Habib, Flexible Pilot Plant Technology for Evaluation of Unconventional Feedstocks and Processes, in: Grace Catalysts Technologies, 2013, pp. 32-60.

[62] H. L. Chum, A. Pinho, U.S. DOE Bioenergy Technologies Office (BETO) 2015 Project Peer Review Excerpt; 2.4.2.303 Brazil Bilateral: PetrobrasNREL CRADA. 
[63] G. Fogassy, N. Thegarid, Y. Schuurman, C. Mirodatos, From biomass to bio-gasoline by FCC co-processing: effect of feed composition and catalyst structure on product quality, Energy \& Environmental Science 4 (12) (2011) 5068. doi:10.1039/c1ee02012a

[64] L. Gueudré, F. Chapon, C. Mirodatos, Y. Schuurman, R. H. Venderbosch, E. Jordan, S. Wellach, R. M. Gutierrez, Optimizing the bio-gasoline quantity and quality in fluid catalytic cracking co-refining, Fuel 192 (2017) 6070. doi:10.1016/j.fuel.2016.12.021.

[65] G. Fogassy, N. Thegarid, G. Toussaint, A. C. van Veen, Y. Schuurman, C. Mirodatos, Biomass derived feedstock co-processing with vacuum gas oil for second-generation fuel production in FCC units, Appl. Catal., B 96 (3-4) (2010) 476-485. doi:10.1016/j . apcatb. 2010.03.008.

[66] Q. Sheng, G. Wang, Y. Liu, M. M. Husein, C. Gao, Q. Shi, J. Gao, Combined Hydrotreating and Fluid Catalytic Cracking Processing for the Conversion of Inferior Coker Gas Oil: Effect on Nitrogen Compounds and Condensed Aromatics, Energy Fuels 32 (4) (2018) 4979-4987. doi: 10.1021/acs.energyfuels.8b00436.

[67] H. S. Cerqueira, G. Caeiro, L. Costa, F. Ramôa Ribeiro, Deactivation of FCC catalysts, J. Mol. Catal. A: Chem. 292 (1-2) (2008) 1-13. doi:10. $1016 / j$.molcata.2008.06.014

[68] M. Guisnet, F. R. Ribeiro, Deactivation and Regeneration of zeolite catalysts, Imperial College Press: UK, 2011.

[69] G. W. Young, Fluid catalytic cracker catalyst design for nitrogen tolerance, J. Phys. Chem. 90 (20) (1986) 4894-4900. doi:10.1021/j100411a035.

[70] A. Imran, E. A. Bramer, K. Seshan, An overview of catalysts in biomass pyrolysis for production of biofuels, Biofuel Research Journal 5 (4) (2018) 872-885. doi:10.18331/BRJ2018.5.4.2. 


\section{Co-processing of Wood and Wheat Straw Derived Pyrolysis Oils with FCC Feed- Product Distribution and Effect of Deoxygenation}

\section{Supporting Information}

Andreas Eschenbacher ${ }^{\mathrm{a}}$, Trond Myrstad ${ }^{\mathrm{b}}$, Niels Bech ${ }^{\mathrm{c}}$, Jens Ø. Duus ${ }^{\mathrm{d}}$, Chengxin Li ${ }^{\mathrm{d}}$, Peter A.

Jensen $^{\mathrm{a}}$, Ulrik B. Henriksen ${ }^{\mathrm{a}}$, Jesper Ahrenfeldt ${ }^{\mathrm{a}}$, Uffe V. Mentzel ${ }^{\mathrm{e}}$, Anker D. Jensen ${ }^{\mathrm{a} *}$

${ }^{a}$ DTU Chemical Engineering, Technical University of Denmark (DTU), Soltofts Plads 229, 2800 Kgs. Lyngby, Denmark

${ }^{b}$ Equinor Forskningssenter Rotvoll, Arkitekt Ebbels vei 10, 7053 Ranheim, Norway

${ }^{c}$ Equinor Danmark A/S, Melbyvej 10, 4400 Kalundborg, Denmark

${ }^{d}$ DTU Chemistry, Technical University of Denmark (DTU), Kemitorvet 207, 2800 Kgs. Lyngby, Denmark

${ }^{e}$ Haldor Topsøe A/S, Haldor Topsøes Allé 1, 2800 Kgs. Lyngby, Denmark

The supporting information consists of 8 pages, 5 tables and 8 figures. 


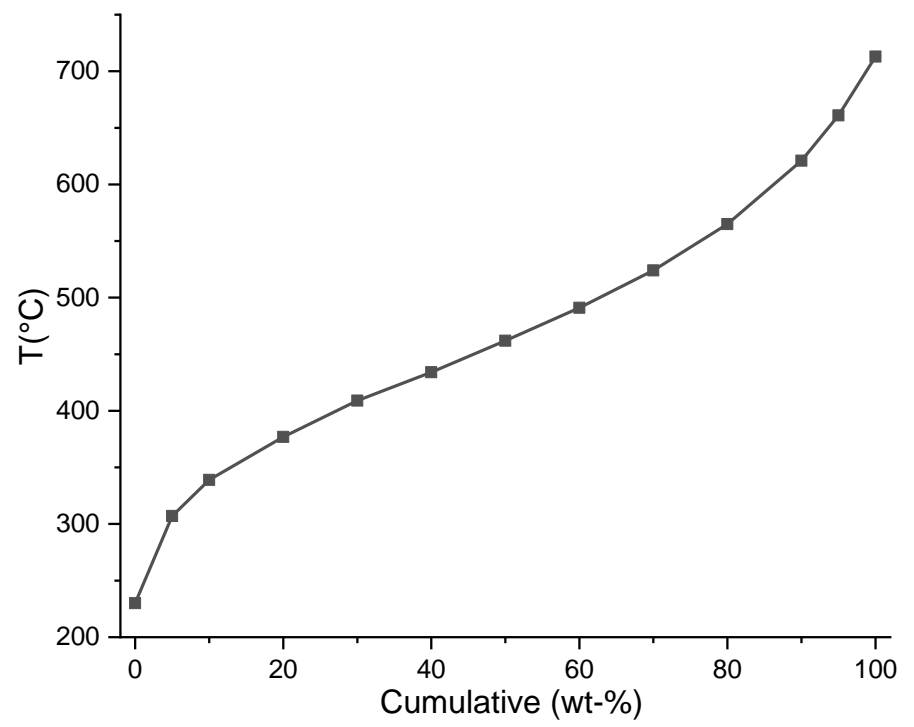

Fig. 1 Boiling point distribution of the reference feed based on high-temperature simulated distillation.

\section{Physicochemical characterization of catalyst used for pyrolysis vapor deoxygenation, according to Table S1}

Table $\mathrm{S} 1$ summarizes the properties of the freshly calcined $\mathrm{HZSM}-5 / \mathrm{Al}_{2} \mathrm{O}_{3}$ extrudate, after steaming, after coke formation from upgrading to $\mathrm{B}: \mathrm{C}=5.6$, and after combustion of the coke species. The Brønsted acidity quantified by Ethylamine-TPD for the steamed HZSM-5 extrudate amounted to $0.154 \mathrm{mmol} \mathrm{NH} / \mathrm{g}$. The steaming and reaction/regeneration cycle decreased the BET surface area from 395 to $353 \mathrm{~m}^{2} / \mathrm{g}$. The coked catalyst obtained after cumulative feeding of biomass to $\mathrm{B}: \mathrm{C}=5.6$ showed both reduced volume of micro- and mesopores, and a reduced BET surface area of $185 \mathrm{~m}^{2} / \mathrm{g}$. Furthermore, the catalyst's acidity has been reduced from $\sim 0.39$ to $\sim 0.05 \mathrm{mmol} \mathrm{NH}_{3} / \mathrm{g}$. The $\mathrm{NH}_{3}$-TPD profiles are proved in Fig. $\mathrm{S} 1$ and show that the strong acidity was completely diminished for the coked catalyst while some weak acidity remained. Combustion of the coke species allowed to regain both weak and strong acidity.

Table S1 Physicochemical properties of HZSM-5/ $\mathrm{Al}_{2} \mathrm{O}_{3}$ extrudate. $\mathrm{V}_{\text {micro }}$ and $\mathrm{S}_{\text {micro }}$ were determined by high-resolution low temperature Argon physisorption $(87 \mathrm{~K})$, while all other textural parameters were derived from nitrogen adsorption data. Total acidity was determined by $\mathrm{NH}_{3}$-TPD. The suffixes 'st', ' $u$ ', and ' $r$ ' to the catalyst designation indicate steaming, upgrading and regeneration, respectively.

\begin{tabular}{|l|c|c|c|c|c|c|c|}
\hline & $\begin{array}{c}V_{\text {micro }} \\
{[\mathrm{cc} / \mathrm{g}]}\end{array}$ & $\begin{array}{c}S_{\text {micro }} \\
{\left[\mathrm{m}^{2} / \mathrm{g}\right]}\end{array}$ & $\begin{array}{c}V_{\text {meso }} \\
{[\mathrm{cc} / \mathrm{g}]}\end{array}$ & $\begin{array}{c}S_{\text {meso }} \\
{\left[\mathrm{m}^{2} / \mathrm{g}\right]}\end{array}$ & $\begin{array}{c}V_{\text {total }} \text { at } \\
\mathrm{p} / \mathrm{p}_{0}=0.99\end{array}$ & $\begin{array}{c}\text { BET (N }) \\
\mathrm{m}^{2} / \mathrm{g}\end{array}$ & $\begin{array}{c}\text { Total Acidity } \\
{\left[\mathrm{mmol} \mathrm{NH}_{3} / \mathrm{g}\right]}\end{array}$ \\
\hline Extr & 0.12 & 865 & 0.31 & 178 & 0.46 & 395 & 0.486 \\
\hline Extr-st & n.a. & n.a. & 0.32 & 171 & 0.45 & 376 & 0.385 \\
\hline Extr-st-u (B:C=0-5.6) & 0.08 & 606 & 0.11 & 67 & 0.18 & 185 & 0.051 \\
\hline Extr-st-u-r & 0.11 & 859 & 0.33 & 177 & 0.44 & 353 & 0.338 \\
\hline
\end{tabular}




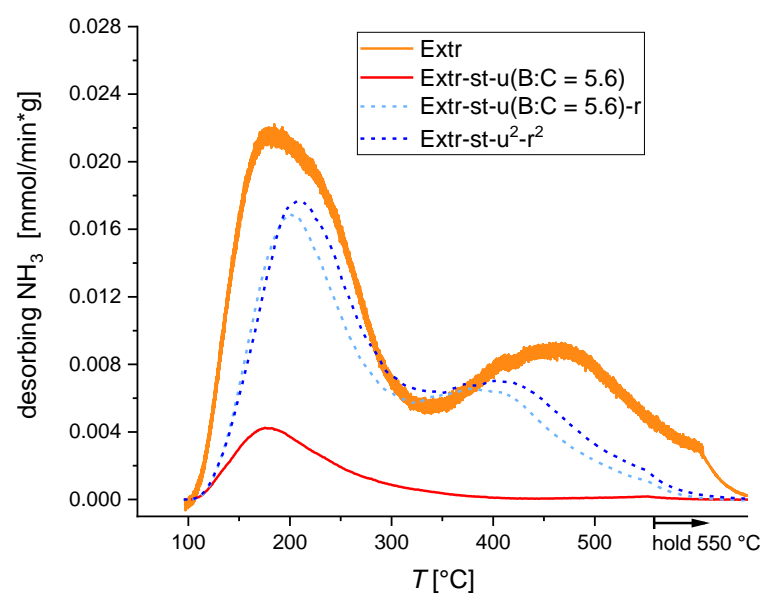

Fig. S2 Acidity characterization (by $\mathrm{NH}_{3}-\mathrm{TPD}$ ) of $\mathrm{HZSM}-5 / \mathrm{Al}_{2} \mathrm{O}_{3}$ extrudates as received, after steaming and use of $260 \mathrm{~g}$ catalyst for upgrading of wheat straw derived pyrolysis vapors $\left(500^{\circ} \mathrm{C}, \mathrm{B}: \mathrm{C}=5.6\right)$, and after the regeneration of the accumulated coke.

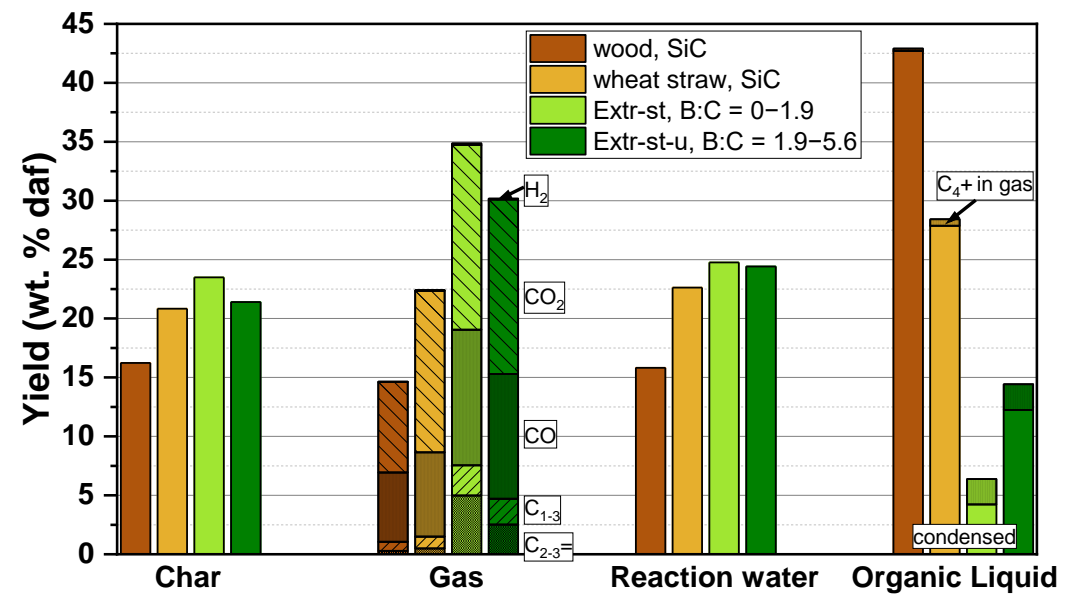

Fig. S3. Product distribution obtained for generation of oils: non-catalytic fast pyrolysis oils from wood (pine) and wheat straw were obtained using a $\mathrm{SiC}$ bed, while the catalytically upgraded oils were obtained using $260 \mathrm{~g}$ steamed HZSM-5 extrudates at 500 ${ }^{\circ} \mathrm{C}$ and wheat straw as feedstock. Coke yield was $5.8 \mathrm{wt}-\%$ of the fed (daf) biomass for the catalytic run when operated to a cumulative B:C ratio of 5.6. 
Table S2. Characterization of moisture (Karl Fischer titration) and elemental analysis of organics content (d.b.) for liquid products obtained for passing wood fast pyrolysis vapors over SiC bed.

\begin{tabular}{|l|c|c|c|c|c|}
\hline Liquid distribution & $\mathbf{4}^{\circ} \mathbf{C} \mathbf{~ O F}$ & $\mathbf{E S P}$ OF & $\mathbf{- 6 0}^{\circ} \mathbf{C} \mathbf{~ O F}$ & $\mathbf{s u m}_{\mathbf{O}} \mathbf{F}^{\mathbf{a})}$ & $\mathbf{s u m ~ W F}^{\mathbf{b})}$ \\
\hline $\begin{array}{l}\text { Yield within total collected } \\
\text { liquid [wt-\%wb] }\end{array}$ & 17.2 & 25.0 & 1.7 & 43.9 & 56.1 \\
\hline Moisture [wt-\%] & 11.9 & 4.9 & 9.6 & 7.8 & 51.5 \\
\hline $\begin{array}{l}\text { Organics distribution within } \\
\text { total collected liquid [wt-\%db] }\end{array}$ & 22.4 & 35.1 & 2.2 & 59.8 & 40.2 \\
\hline Elements [wt-\%db] & & & & & \\
\hline N & 0.2 & 0.0 & 1.8 & 0.2 & n.d. \\
\hline C & 64.9 & 63.0 & 62.9 & 63.7 & 55.2 \\
\hline H & 6.1 & 6.5 & 8.2 & 6.5 & n.d. \\
\hline O & 28.7 & 30.5 & 27.1 & 29.7 & n.d. \\
\hline HHV [MJ/kg] & 26.9 & 26.6 & 28.8 & 26.8 & n.d. \\
\hline TAN [mg KOH/g] & 57.2 & 66.9 & 1.2 & 60.8 & 66.4 \\
\hline
\end{tabular}

a) 'sum OF' is the sum of the three oil fractions to the left. b) 'sum WF' is the sum of aqueous fractions that phase separated from $4^{\circ} \mathrm{C} \mathrm{OF}$ and $-60^{\circ} \mathrm{C} \mathrm{OF}$ (results for individual aqueous fractions not shown). ${ }^{\text {c) }}$ Total collected liquid $=$ sum OF + sum WF

Table S3. Characterization of moisture (Karl Fischer titration) and elemental analysis of organics content (d.b.) for liquid products obtained for passing wheat straw fast pyrolysis vapors over $\mathrm{SiC}$ bed.

\begin{tabular}{|c|c|c|c|c|c|}
\hline Liquid distribution & $4^{\circ} \mathrm{C} \mathrm{OF}$ & ESP OF & $-60^{\circ} \mathrm{C} \mathrm{OF}$ & sum OF & sum WF ${ }^{b)}$ \\
\hline $\begin{array}{l}\text { Yield within total collected } \\
\text { liquid }\left[\mathrm{wt}-\%{ }_{\mathrm{wb}}\right]^{\mathrm{c})}\end{array}$ & 18.0 & 17.6 & 2.4 & 37.9 & 62.1 \\
\hline Moisture [wt-\%] & 27.6 & 2.4 & 8.6 & 14.7 & 76.6 \\
\hline $\begin{array}{l}\text { Organics distribution within } \\
\text { total collected liquid [wt- } \% \mathrm{db} \text { ] }\end{array}$ & 27.3 & 35.9 & 4.5 & 67.8 & 30.5 \\
\hline \multicolumn{6}{|l|}{ Elements [wt-\%db] } \\
\hline $\mathrm{N}$ & 1.8 & 1.3 & 2.2 & 1.6 & n.d. \\
\hline $\mathrm{C}$ & 75.6 & 66.4 & 63.5 & 69.9 & 54.7 \\
\hline $\mathrm{H}$ & 6.7 & 7.1 & 8.6 & 7.1 & n.d. \\
\hline $\mathrm{O}$ & 15.9 & 25.1 & 25.6 & 21.4 & n.d. \\
\hline HHV $[\mathrm{MJ} / \mathrm{kg}]$ & 32.7 & 29.0 & 29.7 & 30.5 & n.d. \\
\hline TAN $[\mathrm{mg} \mathrm{KOH} / \mathrm{g}]$ & 50.8 & 54.1 & 50.5 & 52.5 & 61.4 \\
\hline
\end{tabular}

a) 'sum OF' is the sum of the three oil fractions to the left. 'b) 'sum WF' is the sum of aqueous fractions that phase separated from $4^{\circ} \mathrm{C}$ OF and $-60^{\circ} \mathrm{C}$ OF (results for individual aqueous fractions not shown). ${ }^{c}$ ) Total collected liquid $=$ sum OF + sum WF 
Table S4. Characterization of moisture (Karl Fischer titration) and elemental analysis of organics content (d.b.) for liquid products obtained when passing straw pyrolysis vapors over $260 \mathrm{~g}$ Extr-st, $\mathrm{B}: \mathrm{C}=1.9-5.6$.

\begin{tabular}{|l|c|c|c|c|c|}
\hline Liquid distribution & $\mathbf{4}^{\circ} \mathbf{C} \mathbf{~ O F}$ & $\mathbf{E S P ~ O F}$ & $\mathbf{- 6 0}^{\circ} \mathbf{C} \mathbf{~ O F}$ & $\mathbf{s u m}^{\mathbf{O}} \mathbf{F}^{\mathbf{a})}$ & $\mathbf{s u m ~ W F}^{\mathbf{b}}$ \\
\hline $\begin{array}{l}\text { Yield within total collected } \\
\text { liquid [wt-\%wb] }\end{array}$ & 7.4 & 8.1 & 7.0 & 22.4 & 77.6 \\
\hline Moisture [wt-\%] & 3.8 & 0.6 & 2.7 & 2.3 & 93.6 \\
\hline $\begin{array}{l}\text { Organics distribution within } \\
\text { total collected liquid [wt-\%db] }\end{array}$ & 26.3 & 29.9 & 25.3 & 81.5 & 18.5 \\
\hline Elements [wt-\%db] & & & & & \\
\hline N & 2.6 & 3.2 & 5.0 & 3.6 & n.d. \\
\hline C & 79.9 & 78.7 & 81.0 & 79.8 & 41.4 \\
\hline H & 7.3 & 7.0 & 9.6 & 7.9 & n.d. \\
\hline O & 10.2 & 11.1 & 4.5 & 8.8 & n.d. \\
\hline HHV [MJ/kg] & 35.4 & 34.5 & 39.0 & 36.2 & n.d. \\
\hline TAN [mg KOH/g] & 35.4 & 34.5 & 39.0 & 36.2 & n.d. \\
\hline
\end{tabular}

a) 'sum OF' is the sum of the three oil fractions to the left. 'b) 'sum WF' is the sum of aqueous fractions that phase separated from $4^{\circ} \mathrm{C} \mathrm{OF}$ and $-60^{\circ} \mathrm{C} \mathrm{OF}$ (results for individual aqueous fractions not shown). ${ }^{\mathrm{c})}$ Total collected liquid $=$ sum OF + sum WF

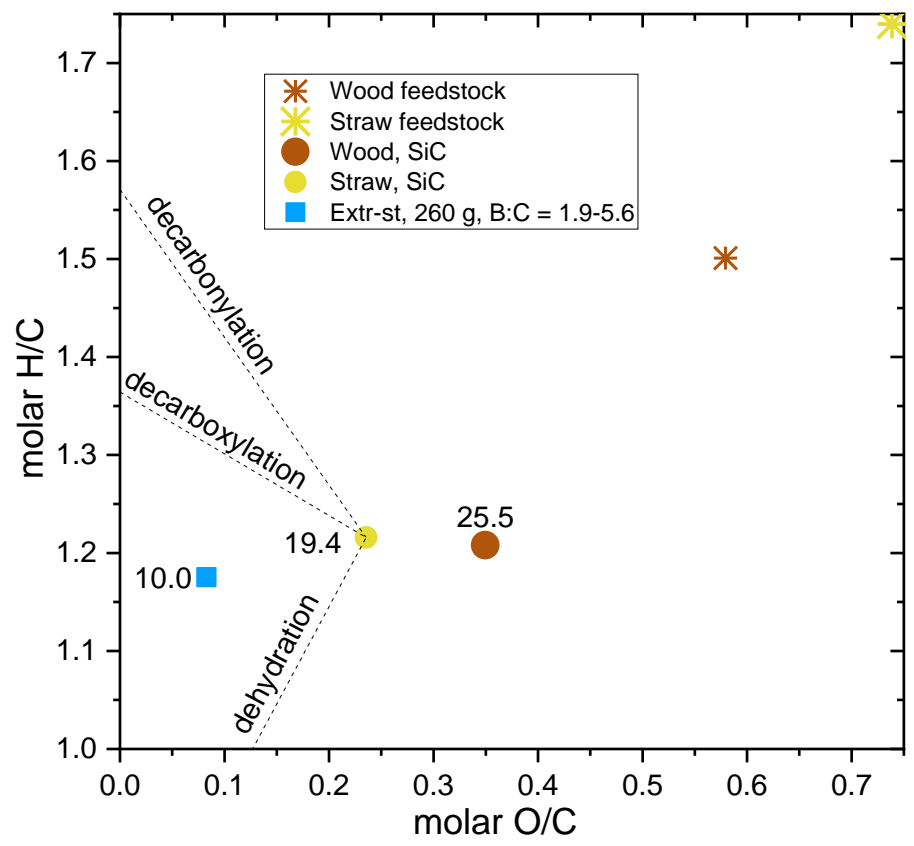

Fig. S4. Molar $\mathrm{H} / \mathrm{C}$ ratio and $\mathrm{O} / \mathrm{C}$ ratio for the phase separated oil fractions obtained from $\mathrm{FP}$ of wood and straw over SiC bed (500 ${ }^{\circ} \mathrm{C}$ ), as well as oil obtained from FP of straw and catalytic upgrading using steamed HZSM-5 extrudates as catalyst. H/C and O/C ratio of feedstock are shown for reference. The numbers besides the data points indicate the yield (on daf basis) of the oil fraction. 


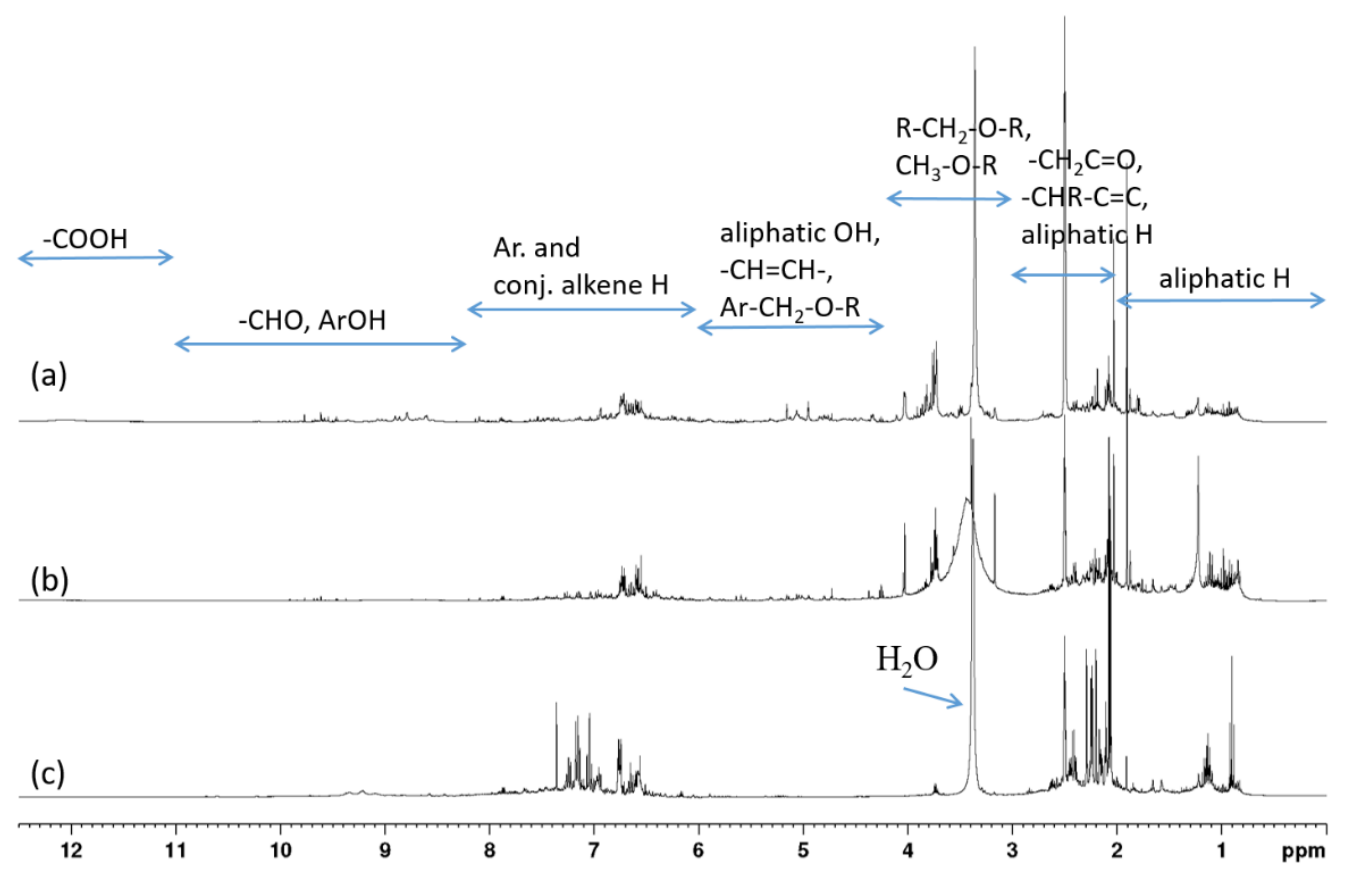

Fig. S5 ${ }^{1} \mathrm{H}$ NMR spectra of oils from FP of wood (a) and straw (b) over SiC bed $\left(500{ }^{\circ} \mathrm{C}\right)$ as well oil obtained from $\mathrm{FP}$ of straw and catalytic upgrading using steamed $\mathrm{HZSM}-5 / \mathrm{Al}_{2} \mathrm{O}_{3}$ extrudates as catalyst at $\mathrm{B}: \mathrm{C}=1.9-5.6(\mathrm{c})$.

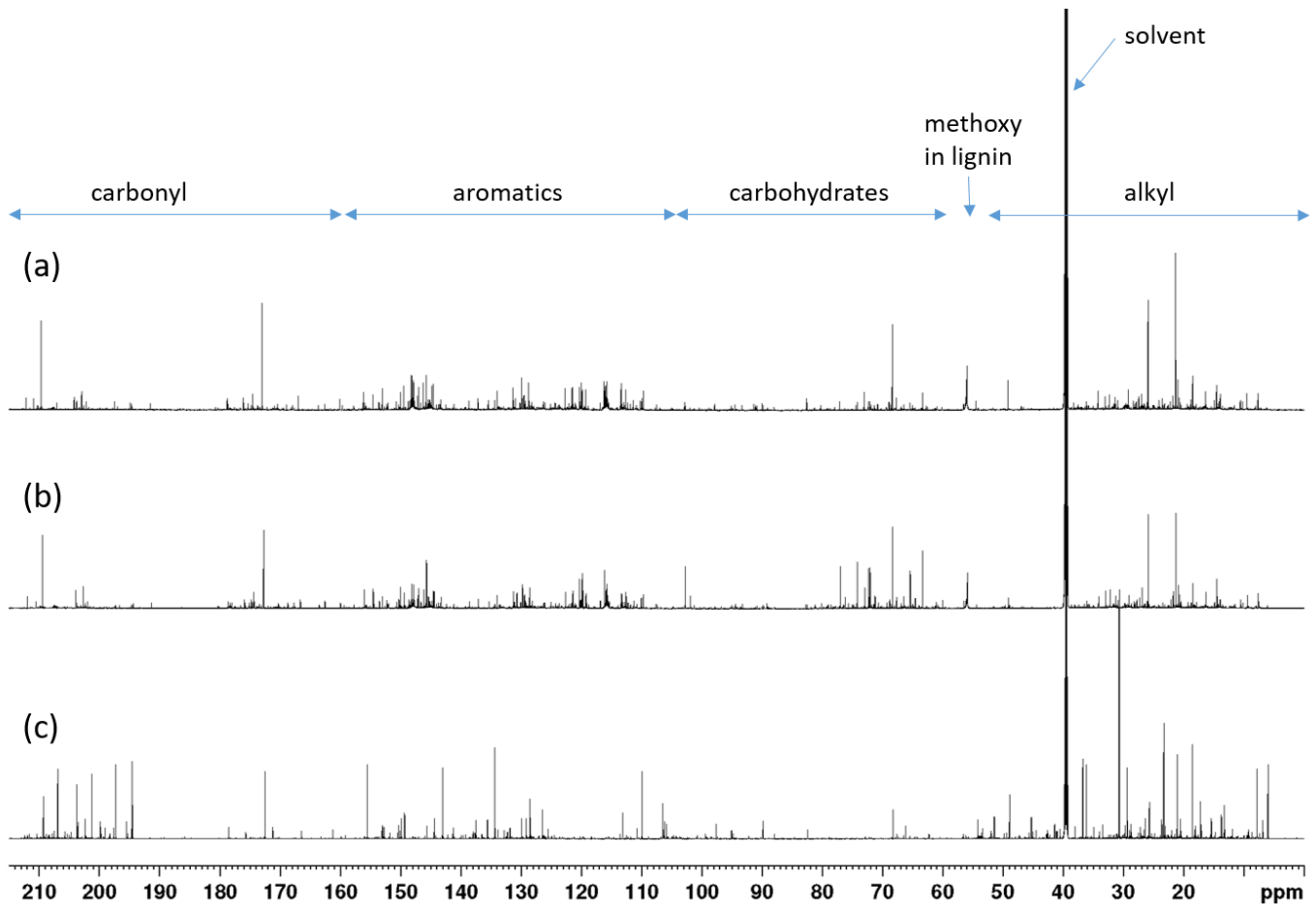

Fig. S6 ${ }^{13} \mathrm{C}$ NMR spectra of oil from wood $\mathrm{FP}$ and passing the vapors over $\mathrm{SiC}\left(500^{\circ} \mathrm{C}\right)$. (a) shows oil collected at $4{ }^{\circ} \mathrm{C}$ condensation stage $\left(4^{\circ} \mathrm{C} \mathrm{OF}\right)(\mathrm{b})$ shows oil collected at electrostatic precipitator (ESP OF), and (c) shows oil collected at a condensation stage operated at $-60^{\circ} \mathrm{C}\left(-60^{\circ} \mathrm{C} \mathrm{OF}\right)$. 


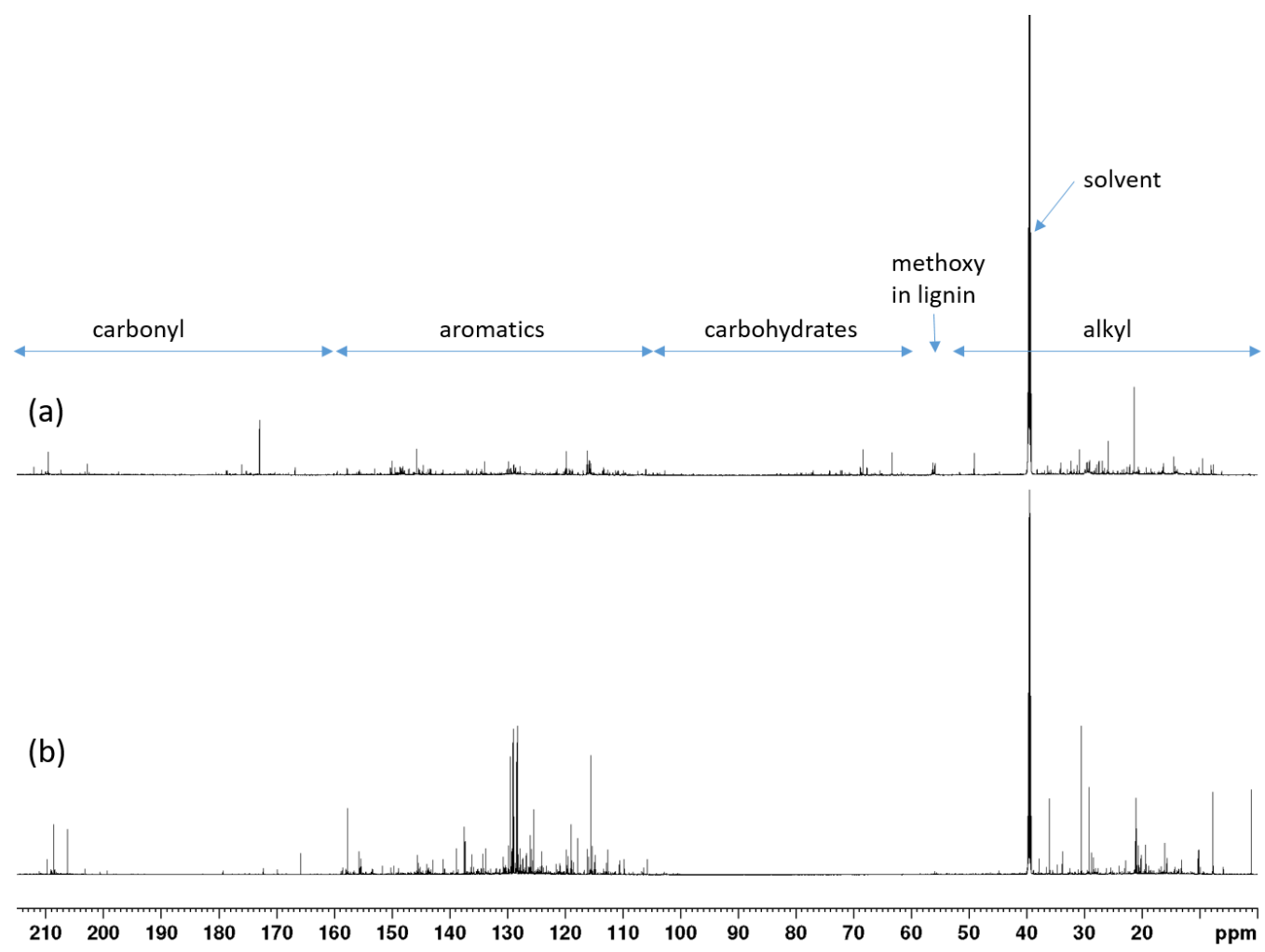

Fig. S7 ${ }^{13} \mathrm{C}$ NMR spectra of oil from straw fast pyrolysis over SiC bed (a) and oil obtained from catalytic vapor upgrading using steamed HZSM-5 extrudates as catalyst at $\mathrm{B}: \mathrm{C}=1.9-5.6$ (b).

Table 5. Characterization of straw derived oil fractions by GC-MS/FID: Shown is the yield of identified compounds with respect to dry, ash-free wheat straw.

\begin{tabular}{|l|c|c|}
\hline & straw, SiC & straw, B:C $=1.9-5.6$ \\
\hline Monoaromatics & wt-\% of biomass (daf) & wt-\% of biomass (daf) \\
\hline Diaromatics & 0.23 & 1.33 \\
\hline Polyaromatics (PAH) & 0.36 & 0.65 \\
\hline Aliphatic hydrocarbons & 0.07 & 0.18 \\
\hline Phenols & 0.58 & 0.64 \\
\hline Methoxy-phenols & 0.59 & 1.79 \\
\hline Furans & 0.22 & 0.11 \\
\hline Acids & 0.27 & 0.14 \\
\hline Esters & 0.68 & - \\
\hline Alcohols & - & 0.23 \\
\hline Aldehydes & 0.53 & 0.58 \\
\hline Ketones & 0.20 & 0.11 \\
\hline Nitrogen containing & 0.84 & 0.87 \\
\hline Oxygenates $<0.1$ wt-\% yield & 0.16 & 0.14 \\
\hline
\end{tabular}




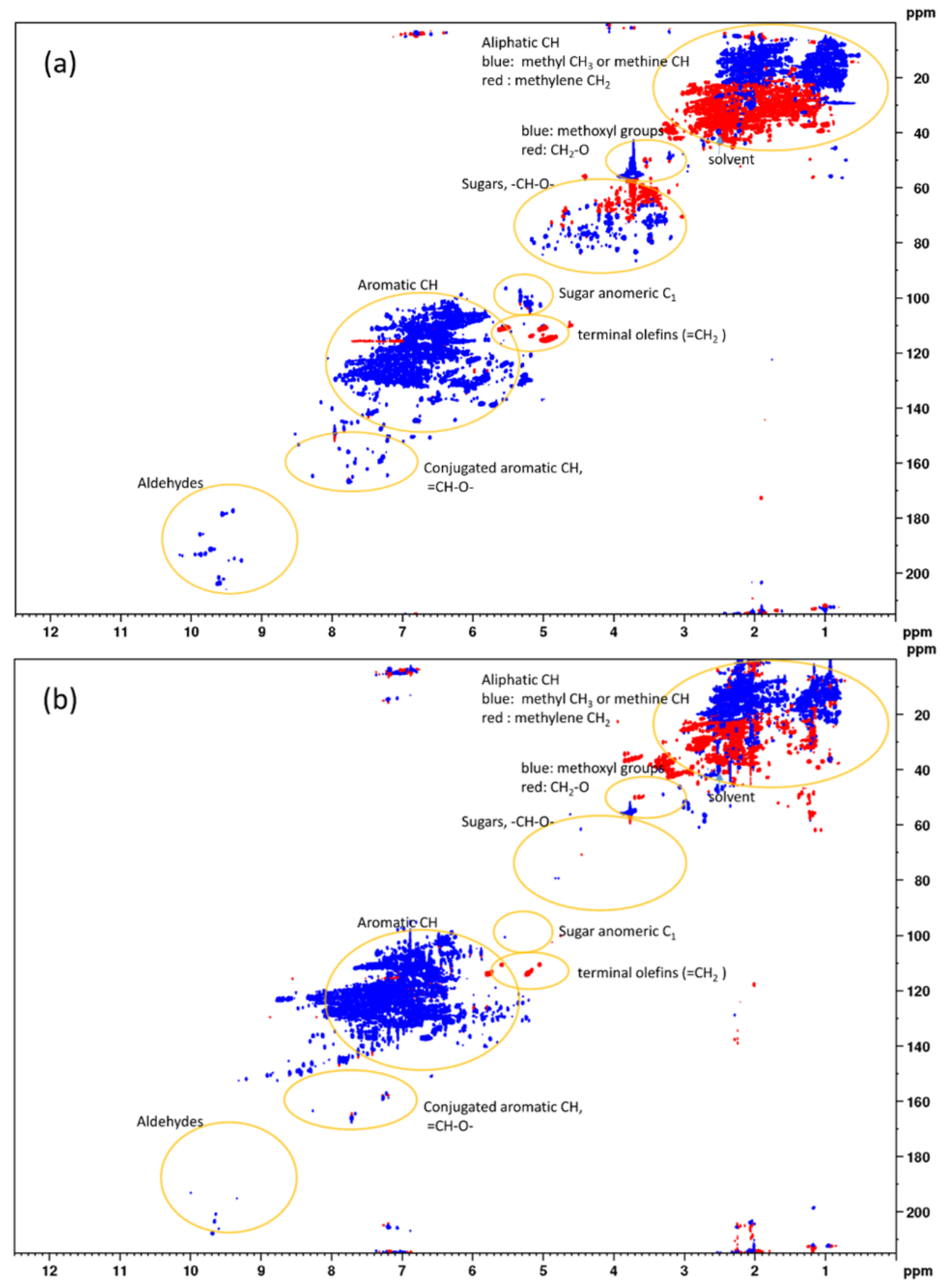

Fig. S8 2D NMR HSQC characterization of oil from straw fast pyrolysis over SiC bed (a) and oil obtained from catalytic vapor upgrading using steamed HZSM-5 extrudates as catalyst at $\mathrm{B}: \mathrm{C}=1.9-5.6$ (b). 